\title{
Lithostratigraphy and biostratigraphy of the Lower Carboniferous (Mississippian) carbonates of the southern Askrigg Block, North Yorkshire, UK.
}

Category: Stratigraphy

C. N. Waters ${ }^{1}$, P. Cózar ${ }^{2}$, I. D. Somerville ${ }^{3}$, R. B. Haslam $^{1}$, D. Millward ${ }^{4} \&$ M. WoODS $^{1}$

${ }^{1}$ British Geological Survey, Environmental Science Centre, Keyworth, Notts, NG12 5GG, $U K$

${ }^{2}$ Instituto de Geociencias CSIC-UCM, Madrid, Spain

${ }^{3}$ UCD School of Geological Sciences, University College Dublin, Belfield, Dublin 4, Ireland

${ }^{4}$ British Geological Survey, Murchison House, West Mains Road, Edinburgh EH9 3LA, $U K$

* Corresponding author (email: cnw@bgs.ac.uk)

Running title: Mississippian carbonates of the Askrigg Block 
Abstract: A rationalized lithostratigraphy for the Great Scar Limestone Group of the southeast Askrigg Block is established. The basal Chapel House Limestone Formation, assessed from boreholes, comprises shallow-marine to supratidal carbonates that thin rapidly northwards across the Craven Fault System, onlapping a palaeotopographical high of Lower Palaeozoic strata. The formation is of late Arundian age in the Silverdale Borehole, its northernmost development. The overlying Kilnsey Formation represents a southward-thickening and upward-shoaling carbonate development on a south-facing carbonate ramp. Foraminiferal/algal assemblages suggest a late Holkerian and early Asbian age, respectively, for the uppermost parts of the lower Scaleber Force Limestone and upper Scaleber Quarry Limestone members, significantly younger than previously interpreted. The succeeding Malham Formation comprises the lower Cove Limestone and upper Gordale Limestone members. Foraminiferal/ algal assemblages indicate a late Asbian age for the formation, contrasting with the Holkerian age previously attributed to the Cove Limestone. The members reflect a change from a partially shallow-water lagoon (Cove Limestone) to more open-marine shelf (Gordale Limestone), coincident with the onset of marked sea-level fluctuations and formation of palaeokarstic surfaces with palaeosoils in the latter. Facies variations along the southern flank of the Askrigg Block, including an absence of fenestral lime-mudstone in the upper part of the Cove Limestone and presence of dark grey cherty grainstone/packstone in the upper part the Gordale Limestone are related to enhanced subsidence during late Asbian movement on the Craven Fault System. This accounts for the marked thickening of both members towards the Greenhow Inlier.

Keywords: Great Scar Limestone Group, Askrigg Block, platform carbonates, microfacies, foraminiferal/algal assemblages 


\section{Introduction}

Modern BGS mapping of the Pateley Bridge area of North Yorkshire (Sheet 61) has provided the opportunity to reappraise the lithostratigraphy and biostratigraphy of the Great Scar Limestone Group present along Upper Wharfedale and in a series of inliers located adjacent to the North Craven Fault (Fig. 1). One of the main aims of this study is to provide a single unified nomenclature for the southern part of the Askrigg Block, associated with the development of a carbonate succession on the tilt-block high. This has been achieved by the synthesis of data from field mapping integrated with borehole and quarry data. The detailed assessment of foraminiferal/ algal assemblages provides an opportunity to assess the established, though not rigorously constrained, biostratigraphical ages previously attributed to the succession. The determination of variations in carbonate facies was used to assess the extent that tectonism and sea-level fluctuation controlled deposition during the Viséan.

\section{Insert Fig. 1}

\section{1.a. History of geological research and survey}

The first systematic mapping across the area was carried out by the Geological Survey at 1:10560-scale during the 1860s. A thick limestone succession was called 'Carboniferous Limestone' during this survey and the name persists in informal use, but this succession has long been referred to as the Great Scar Limestone. This name was formalized as a group on the Askrigg Block by George et al. (1976), but the term is now applied more extensively across northern England from the Isle of Man, the flanks of the Lake District High and across the full extent of the Alston and Askrigg blocks (Waters \& Davies, 2006; Dean et al. 2011). The successions discussed in this study all belong to this group.

The limestones of the Great Scar Limestone Group are mainly bioclastic, often highly bioturbated, with crinoid banks and shelly or coral biostromes. Thin basal beds seen in the Settle area are commonly conglomeratic, with Lower Palaeozoic clasts in a mixed carbonate matrix (Arthurton et al. 1988), though such intervals have not been recorded in the Pateley Bridge study area. Colour, nature of bedding and grain-size variations are the key criteria for distinguishing the component formations and members (Table 1). As is common with other Viséan platform areas of the British Isles, the group shows a trend from dark or mid-grey Arundian to Holkerian carbonates (e.g. Kilnsey Formation) to pale grey late Asbian limestones (e.g. Malham Formation).

\section{Insert Table 1}

The Great Scar Limestone Group includes many local formations, with distinct nomenclatures for the isolated successions on the various tectonic blocks. Even within the more limited area of the Askrigg Block in North Yorkshire several different lithostratigraphic schemes exist (see Dunham \& Wilson, 1985) and despite attempts at rationalization, three separate successions have evolved (Table 1) for the north, southwest (Settle area) and southeast (Greenhow Inlier) parts of the block.

The southern condensed succession that accumulated on the Askrigg tilt-block high passes northwards toward the Stainmore Basin. These lateral facies changes result in classification of a distinct northern stratigraphy, recorded in two deep boreholes (Raydale Borehole BGS Registration Number SD98SW1 and Beckermonds Scar Borehole SD88SE1; Fig. 1a), and summarized by Dunham \& Wilson (1985) and listed in Table 1. 
The existing stratigraphy for three distinct areas along the south Askrigg Block; the Settle and Horton in Ribblesdale area, the Greenhow and Skyreholme inliers, and the Cracoe Reef complex (Fig. 1) is summarized below.

\section{1.b. Settle and Horton in Ribblesdale}

A nomenclature developed for the Horton in Ribblesdale and Settle areas comprising, in ascending order, 'Michelinia grandis Beds' and 'Gastropod Beds' of Garwood \& Goodyear (1924) and Horton Limestone and Kingsdale Limestone of George et al. (1976) has been superseded by subsequent mapping on the Settle sheet with a succession comprising, in ascending order, the Chapel House Limestone, Kilnsey and Malham formations (Arthurton et al. 1988).

The Chapel House Limestone Formation has been proved in several boreholes along the southern flank of the Askrigg Block, including the Chapel House Borehole (BGS registration number SD96NE1) in the Pateley Bridge area (Fig. 1b; Arthurton et al. 1988). The most northerly development of the formation is proved in the Silverdale Borehole (SD87SW9), east of Horton in Ribblesdale (Fig. 1a). Much emphasis has been placed in this study on this borehole for constraining the age-ranges of the carbonate succession on the Askrigg Block. However, other than the work of F. M. White (unpub. Ph.D. thesis, Univ. Manchester, 1992), data from this borehole are unpublished. Consequently, the borehole has been resectioned and a study of the foraminiferal/algal assemblages undertaken on a new suite of thin sections housed in the BGS Palaeontological Collection.

The Kilnsey Formation was subdivided by Arthurton et al. (1988) into the Arundian Kilnsey Limestone-with-mudstone and Scaleber Force Limestone Member and Holkerian Kilnsey Limestone and Scaleber Quarry Limestone. Given these authors' recognition that the ageequivalent units were lithologically similar, Dean et al. (2011) formalized the succession as the Scaleber Force Limestone (lower) and Scaleber Quarry Limestone (upper) members. The latter is broadly equivalent to the Fawes Wood Limestone Formation on the north Askrigg Block (Table 1).

The Malham Formation was subdivided into a lower Cove Limestone of Holkerian age and an upper Gordale Limestone of Asbian age by Arthurton et al. (1988). This subdivision was subsequently formalized as members by Dean et al. (2011). Importantly, description of the Malham Formation in the eastern part of the Settle Sheet (Sheet 60) by Arthurton et al. (1988) is very limited. There is no direct equivalent of the Cove Limestone in the north Askrigg Block, where the Garsdale Limestone Formation is dominantly dark grey with common mudstone beds, although the overlying Danny Bridge Limestone Formation is comparable with the Gordale Limestone (Table 1). The Cove Limestone and Gordale Limestone members are broadly lithologically equivalent with the Park Limestone and Urswick Limestone formations, respectively, of south Cumbria.

\section{1.c. Greenhow and Skyreholme Inliers}

The geology of the Skyreholme Anticline, including a key section at Trollers Gill, was provided by Anderson (1928), whose map was subsequently revised by Hudson (1938, p. 311). Dunham \& Stubblefield (1945) described the detailed litho- and bio-stratigraphy, and structure of the Greenhow Inlier, although this pre-dated the expansion of the Coldstones Quarry. This, and the more comprehensive summary of the stratigraphy, structure and mineralization of the Askrigg Block by Dunham \& Wilson (1985) have provided the de facto 
lithostratigraphy for both inliers, comprising, in ascending order: Timpony Limestone, Stump Cross Limestone, Greenhow Limestone and Hargate End Limestone formations (Table 1). This nomenclature pre-dates the stratigraphical succession defined in the Settle district by Arthurton et al. (1988), and sufficient uncertainty as to how these schemes were related led Dean et al. (2011) and subsequently Waters \& Lowe (2013) and Lowe \& Waters (2014), not to modify the scheme used for the Greenhow Inlier. However, the current study, as described below, has been unable to justify continued usage of this stratigraphy within the inliers.

\section{1.d. Cracoe Reef complex}

'Cracoean' reefs occur along the southern margin of the Askrigg Block, located south of the Middle Craven Fault, in a roughly west-east tract extending $20 \mathrm{~km}$ eastwards from Settle to Burnsall (Fig. 1a). Formerly referred to as Marginal Reef Limestones of the Malham Formation (Arthurton et al. 1988), they have been redefined subsequently as the Cracoe Limestone Formation (Dean et al. 2011; Table 1). This study did not investigate the complex development of these Cracoean reefs, which will be the subject of subsequent work.

\section{Revised lithostratigraphy and biostratigraphy}

In this section a unified lithostratigraphy is applied across the three areas described above. Importantly, the application of new biostratigraphical interpretations, principally of foraminifers and algae/problematica (see Tables 2-4), permits correlation between the three areas and a revision of the established age ranges of the lithostratigraphic units. These are summarised in Figure 2. The Chapel House Limestone, Kilnsey Formation, Cove Limestone and Gordale Limestone members of the Malham Formation are described respectively in sections 2.a. to 2.d.

Only the most distinctive components of the macrofaunas, mainly brachiopods, with a few corals and bivalves, are listed. The range data for the macrofauna are given by Riley (1993), Wilson, (1989), Dunham \& Wilson (1985), Arthurton et al. (1988), Cossey et al. (2004) and the Palaeobiology Database (http://fossilworks.org/cgi-bin/bridge.pl?a=home). The biostratigraphy of the foraminifers is adopted from the pioneer papers by Conil et al. (1980), Strank (1981), Laloux (1987), and subsequent modifications mostly in Conil et al. (1991), Riley (1993) and Cózar \& Somerville (2004). Key foraminifers identified during the current study are illustrated in figures $3 \& 4$. Sample numbers are italicized, with location details provided in Table 5.

\section{Insert Figs. 2-4 and Tables 2-5}

\section{2.a. Chapel House Limestone Formation}

2.a.1. Lithostratigraphy

The Chapel House Limestone Formation was introduced in the Settle district by Arthurton et al. (1988) for the succession which underlies the Kilnsey Formation and either unconformably overlies the Tournaisian Stockdale Farm Formation or Lower Palaeozoic rocks. In the type section, the Chapel House Borehole, the formation is $33.6 \mathrm{~m}$ thick. The formation is thickest (56 m) in the Stockdale Farm Borehole (SD86SE6; Fig. 1a), adjacent to the Middle Craven Fault. Elsewhere to the north of the North Craven Fault, the formation onlaps, and is locally absent over topographic highs in the Lower Palaeozoic basement and is only $12 \mathrm{~m}$ thick in the Silverdale Borehole (Murray, 1983).

In the Settle district, the lower part of the formation is dominated by medium to medium-light grey, medium and coarse grainstone with common Lower Palaeozoic lithoclasts, locally 
forming conglomerates, and the notable presence of ooids (Arthurton et al., 1988). Other common lithologies are 'mixed laminites' comprising interbedded fissile siltstone with sandstone and mudstone laminae, dolomite-mudstone and lime-mudstone with fenestral textures or algal lamination and argillaceous wackestones are present in the upper part of the formation in the Kilnsey area (Arthurton et al., 1988).

The unconformable base of the Chapel House Limestone Formation in the Silverdale Borehole is overlain by medium grey, fine- to medium-coarse-grained packstone/grainstone with abundant crinoid and brachiopod debris, quartz grains and peloids (Fig. 5). The upper $5.5 \mathrm{~m}$ is marked by medium and dark grey lime-mudstone and laminated argillaceous wackestone with fenestral fabrics, abundant quartz grains in laminae and intraclasts with common ostracods and dasycladal green algae. The upper boundary of the formation is marked by a change from lime-mudstone to darker grey coarser grained bioclastic packstones/wackestones of the Kilnsey Formation.

\section{Insert Fig. 5}

\section{2.a.2. Biostratigraphy}

Macrofossils: The Chapel House Limestone Formation is equivalent to the lower part of the Michelinia Zone $\left(\mathrm{C}_{2}\right)$ of Garwood \& Goodyear (1924). Michelinia megastoma, found near the top of the formation at Stainforth Beck [38198 46700] and Palaeosmilia murchisoni recovered from the base of the Chapel House Limestone at $191 \mathrm{~m}$ depth in the Silverdale Borehole, were considered to indicate an Arundian age (Arthurton et al. 1988).

Microfossils: Foraminifers from the Chapel House and Stockdale Farm boreholes and from Gordale Beck (Fig. 1a) confirm an Arundian age (Arthurton et al. 1988), the diagnostic taxa being Ammarchaediscus (=Viseidiscus) bucullentus, Eoparastaffella simplex (Fig. 3a), Glomodiscus miloni, Latiendothyranopsis menneri solida and Rectodiscus (=Uralodiscus) sp.

In the Silverdale Borehole (Fig. 5, Table 4), the basal sample of the Chapel House Limestone Formation (EWJ1575), located immediately above the basal unconformity upon Lower Palaeozoic basement contains all of the diagnostic taxa of a late Arundian age, including Glomodiscus rigens (Fig. 3g), Uralodiscus adindanii (Fig. 3h), U. rotundus, U. settlensis (Fig. 3i), Viseidiscus monstratus, Paraarchaediscus at involutus stage, Plectogyranopsis moraviae (Fig. 4g), Eoparastaffella simplex (EWJ1572-75), Latiendothyranopsis menneri solida (EWJ1573-75; Fig. 4c), Eoendothyranopsis, Pseudolituotubella, Nodoarchaediscus and Koninckopora spp. This sample has the richest (35 foraminiferal species) and most diverse assemblage for any sample in the borehole. It also agrees with many of the taxa illustrated by Conil et al. (1980) from the Arundian Michelinia Grandis Beds at Settle and characteristic of his Cf4 $\delta$ subzone.

Also in the Silverdale Borehole (Fig. 5), a sample (EWJ1573) located $2 \mathrm{~m}$ above the basal sample has less species richness (20) and many Arundian taxa no longer present, but still records the last occurrences of taxa typical of the late Arundian. Some first appearances are still distinctive of the Arundian (e.g. Condrustella, Fig. 3o) and Lituotubella magna (Fig. 4a). The latter taxon was recorded by Strank (1981) from the upper part of the Arundian Dalton Formation close to the contact with the Holkerian Park Limestone Formation in the stratotype Holkerian section at Barker Scar, Cumbria (Ramsbottom, 1981; Waters, 2011). The micritic 
beds with fenestral fabrics in the upper $5.5 \mathrm{~m}$ of the Chapel House Limestone are barren of foraminifers.

\section{2.b. Kilnsey Formation}

\section{2.b.1. Lithostratigraphy}

The Kilnsey Formation, the type locality of which forms Kilnsey Crag (Figs $1 \& 6$ ), comprises two distinct units (Arthurton et al. 1988; Table 1). The lower Scaleber Force Limestone Member (also Kilnsey Limestone-with-mudstone) is a dark grey, fine- to coarsegrained, argillaceous, bioclastic and peloidal packstone and subordinate wackestone, with common detrital quartz and beds of mudstone up to $1.8 \mathrm{~m}$ thick (Arthurton et al. 1988). The uppermost part of the member at the type locality $(P c 4833)$ is a parallel laminated, argillaceous kamaenid algal packstone dominated by common crinoids, with subordinate brachiopods and bryozoans and minor micritic intraclasts. This member is comparatively more argillaceous than the overlying Scaleber Quarry Limestone Member (also Kilnsey Limestone), which is $29 \mathrm{~m}$ thick at Kilnsey Crag and typically comprises medium to dark grey, well bedded, fine- to coarse-grained, bioclastic packstone or grainstone (Arthurton et al. 1988).

East of Kilnsey Crag, the uppermost part of the Scaleber Quarry Limestone Member is exposed at the bottom of Conistone Dib (Fig. 1b). The succession (Pc4820) comprises medium grey, thick-bedded $(0.6 \mathrm{~m})$, coarse-grained, densely packed packstone with crinoidal debris, some brachiopod valves and small micritic intraclasts (Fig. 7). Bioclasts and peloids are moderately sorted, with a poorly defined cross-lamination. The bioclasts are dominated by crinoids with minor components of syringoporoids, bryozoans and brachiopods.

In the Greenhow and Skyreholme inliers (Fig. 1b), the absence of a thick interval of 'dark grey limestone' was used by Dunham \& Wilson (1985) to justify that the equivalent of the Kilnsey Formation was absent at outcrop; our study confirms that interpretation. However, the Scaleber Quarry Limestone Member is considered to be present in the subsurface in Coldstones No. 4 Borehole below 295.2 m (BGS Registration number SE16SW5; Fig. 8). Interpreted as the lower part of the Stump Cross Limestone and Timpony Limestone by Strank (1982b), this succession is distinctly dominated by medium grey, fine- to medium- or medium-grained limestone, partly dolomitized, with brachiopods, crinoid and coral beds. A thickness for this member of more than $128 \mathrm{~m}$ in this borehole is comparable with $135 \mathrm{~m}$ recorded in the Cominco S2 Borehole (SD86SW6; Fig. 1a) near Settle (Arthurton et al. 1988).

The Kilnsey Formation in the Silverdale Borehole is 33m thick (Murray, 1983) and is a relatively uniform facies of medium to dark grey, fine- to medium-grained packstones and grainstones with shelly fauna, although some fenestral lime-mudstones are interbedded (Fig. 5). This contrasts with Murray (1983) who described the succession between 146.52-171.96 $\mathrm{m}$ of grainstone at base, otherwise wackestone and locally packstone. This is still a moderately shallow-water shelf facies with crinoids, brachiopods, bryozoans, corals, foraminifers and dasyclads and rare ooids. The presence of intraclasts is of some interest, but not distinctive, as they are also present in the overlying Cove Limestone Member. The upper boundary at $146.52 \mathrm{~m}$ marks a clear colour change from the mainly dark packstone/wackestone of the Kilnsey Formation to paler coarser grained packstone/grainstone of the overlying Cove Limestone Member. The Kilnsey Formation is thin when compared to Kilnsey Crag. The absence of common argillaceous beds suggests that the Scaleber Force Limestone Member is absent and only the equivalent of the Scaleber 
Quarry Limestone Member is present in the Silverdale Borehole. The presence of rare ooids within the lower part of the Kilnsey Limestone in this borehole is unusual, but is quite common in the underlying Chapel House Limestone Formation.

\section{2.b.2. Biostratigraphy}

Macrofossils: The Scaleber Force Limestone Member is approximately equivalent to the upper part of the Michelinia Zone $\left(\mathrm{C}_{2}\right)$ of Garwood \& Goodyear (1924), and the lowest unit (the Gastropod Beds) of their Productus corrugato-hemisphericus Zone (S) (Arthurton et al. 1988). An Arundian age for the Scaleber Force Limestone Member is confirmed by the presence of the brachiopod Delepinea carinata at Mill Scar Lash, River Wharfe [29796 46638], and by the incoming of the corals Siphonodendron martini and Palaeosmilia murchisoni (Arthurton et al. 1988). Brachiopods are dominated by Megachonetes spp. with common Schizophoria resupinata (Arthurton et al. 1988).

The Scaleber Quarry Limestone Member is the equivalent of the Cyrtina carbonaria Subzone $\left(\mathrm{S}_{2}\right)$ of Garwood \& Goodyear (1924), together with the lower part of their Nematophyllum minus Subzone $\left(\mathrm{S}_{2}\right)$. The presence of the cerioid coral Lithostrotion (Nematophyllum) minus, and the brachiopods Composita ficoidea, rare Davidsonina carbonaria, Linoprotonia ashfellensis, L. corrugatohemispherica, confirm a Holkerian age (Arthurton et al. 1988). The fasciculate coral Siphonodendron scaleberense was also first recorded from Scaleber Quarry (Nudds \& Somerville, 1987). Dunham \& Wilson (1985) noted the presence of the corals Lithostrotion minus and L. (=Siphonodendron) sociale and the brachiopod Linoprotonia ashfellensis in the Coldstones No. 4 borehole below $306 \mathrm{~m}$ (Fig. 8), which they also considered to have a Holkerian aspect.

Microfossils: Foraminifers from the Chapel House, Stockdale Farm and Cominco S10 (BGS Registration number SD86SW8) boreholes (Fig. 1a) were used by Strank (in Arthurton et al. 1988) to confirm an Arundian age (Cf4) for the Scaleber Force Limestone Member. Diagnostic taxa recorded for these boreholes include Ammarchaediscus (=Viseidiscus) bucullentus, Brunsiarchaediscus (=Planoarchaediscus) sp., Glomodiscus miloni, Plectogyranopsis moraviae, Pseudolituotubella hibernica, Rectodiscus (=Uralodiscus) sp. and Tubispirodiscus (=Uralodiscus) settlensis. Conil et al. (1980) also analyzed samples from the Scaleber Force Limestone Member at the type locality of Scaleber Force, which they assigned to the Arundian. However, they identified a specimen as cf. Omphalotis minima, whereas the illustrated specimen can be readily assigned to the nominal species. As Conil et al. (1980) recognized, O. minima is one of the guides for the Holkerian (Cf5). The typical assemblage for the Scaleber Force Limestone Member is similar to the basal bed of the Chapel House Limestone in the Silverdale Borehole (see above).

For the Scaleber Quarry Limestone Member a foraminiferal assemblage reported by Strank (in Arthurton et al. 1988) included Archaediscus at angulatus stage (probably transitional forms), A. at concavus stage, Koskinotextularia cribriformis, Nibelia (= Pojarkovella) nibelis, and Nodosarchaediscus sp., confirming a Holkerian age (Cf5) for this succession.

Kilnsey Crag shows the transition between the two members of the Kilnsey Formation (Fig. 6). Strank (in Dunham \& Wilson, 1985) reported that the lowest $7 \mathrm{~m}$ of the section, representing the top of the Scaleber Force Limestone, yielded the foraminifers Ammarchaediscus (=Viseidiscus), Glomodiscus and Rectodiscus (=Uralodiscus) but no diagnostic Holkerian genera. Whereas immediately above that level, and approximately coinciding with the base of the Scaleber Quarry Limestone Member, Strank reported the 
incoming of Koskinotextularia sp. followed higher up by Endothyranopsis crassa (probably E. compressa trans. crassa), Nevillella (=Mstinia) sp., Nibelia (= Pojarkovella) nibelis and nodose archaediscids, and accompanying Brunsia spirillinoides, Eostaffella parastruvei, Glomospiranella dainae and Septabrunsiina sp. which form a characteristic Holkerian foraminiferal assemblage (Table 2).

\section{Insert Fig. 6}

Resampling of the uppermost part of the Scaleber Force Limestone Member at Kilnsey Crag (Pc4833) records diverse foraminifers (Table 2) of which Archaediscus at concavus stage transitional forms to the angulatus stage, large A. aff. chernoussovensis, Endothyranopsis compressa and Nodosarchaediscus spp. indicate a late Holkerian age (Cf5) (Conil et al. 1980; Strank, 1981).

The top of the Scaleber Quarry Limestone Member at Conistone Dib (Pc4820; Fig. 7), records the presence of Archaediscus at angulatus stage, Endothyranopsis compressa trans. crassa, Globoendothyra globulus and Nodosarchaediscus spp., as well as the algospongia Zidella maxima (Table 2). Although the stratigraphic range of the latter is poorly known, it has been associated to the late Viséan upward ( $\geq$ Cf6 $\gamma$ ) (Vachard \& Cózar, 2010). The foraminifers are typically recorded from the early Asbian (Cf6 $\alpha-\beta)$ in Western Europe (Conil et al. 1980).

\section{Insert Fig. 7}

In the Greenhow Inlier, the lower part of the Coldstones No. 4 Borehole (Fig. 8), below $c$. $225 \mathrm{~m}$, contains a sparse foraminiferal assemblage including Archaediscus sp., A. stilus, Endothyranopsis crassa (most probably E. compressa trans. crassa), Eostaffella sp., Consobrinella consobrina, Pseudoammodiscus volgensis, Omphalotis cf. minima, Nodosarchaediscus sp., Brunsia sp. and Valvulinella sp. and common alga Koninckopora inflata (Strank, 1982b; Table 3), which Strank attributed as Holkerian. The more fossiliferous part of the borehole from 325.9 to $295.15 \mathrm{~m}$ depth was interpreted as Holkerian to possibly early Asbian age (Strank, 1982c). The foraminifers from the lower part of the borehole, although sparse and lacking many characteristic taxa are most probably early Asbian age $(\mathrm{Cf} 6 \alpha-\beta)$ as they include some species not known in the Holkerian; the lack of diversity and diagnostic taxa suggests this interval is not late Asbian (Cf6 $\gamma)$ in age.

\section{Insert Fig. 8}

In the Silverdale Borehole (Fig. 5, Table 4), the incoming of Holkerian taxa coincides with the base of the Kilnsey Formation (EWJ1567), especially with Paraarchaediscus at concavus stage and Omphalotis minima (Fig. 4d), with Pojarkovella sp. (EWJ1566), and Holkeria (EWJ1563, Fig. $3 \mathrm{~m}$ ) appearing in the lower part of the formation. The diagnostic Holkerian taxa appear together in the middle of the Kilnsey Formation (EWJ1562) with the FAD of Koskinotextularia sp. (Fig. 31), Eostaffella parastruvei (Fig. 3p) and Mikhailovella, and with Pojarkovella nibelis (EWJ1561), the latter occurring some $14.5 \mathrm{~m}$ above the base of the first Holkerian taxa. The FAD of Endothyranopsis trans. crassa and Paraarchaediscus at angulatus stage in the upper part of the Kilnsey Formation (EWJ 1560) is indicative of an early Asbian age, followed near the top of the formation by Nodasperodiscus and Consobrinella consobrina (EWJ1558). The absence of Vissariotaxis from this early Asbian part of the succession is noteworthy, but is considered a result of the shallow-water facies 
evident in this borehole. The FAD of Neoarchaediscus aff. incertus, N. stellatus and Koskinobigenerina (EWJ1554, Fig. 3d) from the very topmost bed of the Kilnsey Formation marks the incoming of late Asbian taxa.

In summary, existing published information, mainly based upon coral/brachiopod assemblages, indicates an Arundian age for the Scaleber Force Limestone Member and a Holkerian age for the Scaleber Quarry Limestone Member (Arthurton et al. 1988). This contrasts with our study, in which the foraminiferal/algal assemblages suggest a late Holkerian and early/late Asbian age, respectively, for the upper parts of the two members (Table 2). The Coldstones No. 4 Borehole (Fig. 8), in the Greenhow Inlier, includes a succession lithologically comparable with the Scaleber Quarry Limestone Member and with a similar fauna of probable early Asbian age.

\section{2.c. Cove Limestone Member (Malham Formation)}

\section{2.c.1 Lithostratigraphy}

The Cove Limestone Member, the lower part of the Malham Formation, is named after Malham Cove [3896 4642] (Fig. 1a), where it forms the lower part of the cliff face (Arthurton et al. 1988). This member is typically pale grey, massive to weakly-bedded

packstone/grainstone lacking prominent palaeokarstic surfaces (Table 1) and typically forms a landscape with grassy slopes. Distinctive lime-mudstones (micrites) beds with fenestral fabrics occur mainly within the upper part of the member (Arthurton et al. 1988). The c. 1.5 m-thick 'Porcellanous Bed' has been used as a marker (e.g. Garwood \& Goodyear, 1924; Ramsbottom, 1974) for the top of the Horton Limestone (= top of Cove Limestone Member), but this facies is shown to disappear both northwards towards the Stainmore Basin and southwards where it is not recorded south of the North Craven Fault (Arthurton et al. 1988), or within the current study area.

Above the Kilnsey Formation at Kilnsey Crag (Fig. 6), the Cove Limestone Member comprises coarsely bioclastic packstone/grainstone and is strongly bedded, e.g. at Cool Scar Quarry [39692 46751]. An entire thickness of the member $(80 \mathrm{~m})$ is recorded at Conistone Dib (Figs. 1b \& 9a), comprising very thick beds of pale grey packstone/grainstone with less prominent bedding surfaces and some pale brown dolomitization (Fig. 7). The basal (Pc4821-3) and middle parts of the section (Pc4826 \& Pc4828) comprise bioclastic/peloidal grainstone, with common crinoids, foraminifers and intraclasts, with a poorly developed cross-lamination developed in some beds and rare oncoids (Pc4826). The middle of the section (Pc4824\& $\& c 4825)$ also includes finer-grained bioclastic/peloidal grainstones with more dasycladals and locally (Pc4827) crinoidal/algal packstone with many small intraclasts. The upper part of the member (Pc4830 \& Pc4831) comprises bioclastic peloidal grainstones with large brachiopod shells marking a cross-lamination.

\section{Insert Fig. 9}

In the Skyreholme Inlier (Fig. 1b), Dunham \& Wilson (1985) equated the Timpony Limestone with the Cove Limestone Member. However, there is little lithological similarity between the two units (Table 1) and it is assumed that the correlation was based on age. The key section at Trollers Gill (Figs $1 \mathrm{~b} \&$ 9b) was mapped previously as ' $\mathrm{S}$ Beds' by Anderson (1928), who recognized an upward succession of white 'limestone and lime-mudstone, light grey slightly crinoidal limestone, and capped by porcellanous limestone' with the first appearance of productid brachiopods. The section is lithologically very similar in appearance to the Cove Limestone Member at Conistone Dib, with a monotonous development of at least 
$25 \mathrm{~m}$ of broadly upward-coarsening, massive to very thick-bedded, pale grey packstone/grainstone (Fig. 7). The lower part (DMA320-323) is fine- to medium-grained, skeletal (crinoidal-algal-rich) and peloidal packstone /grainstone, locally with abundant limestone intraclasts. The basal part of this succession (DMA320) includes coated grains and sparse ooids, large cavities containing sparry cements, peloids in geopetal sediment, and large limestone intraclasts. The upper part of the succession in the gorge (DMA324-326) is medium- and medium- to coarse-grained, moderately and well sorted, skeletal (crinoidalalgal-rich) packstone.

The Stump Cross Limestone of Dunham \& Stubblefield (1945) and Dunham \& Wilson (1985) is named after the eponymous showcave located in the Skyreholme Inlier. The base of the unit was taken at the base of the 'Hemitrypa Bed', a c. $0.8 \mathrm{~m}$-thick 'pale brown (fawn) bioclastic limestone, overlain by buff dolomitic limestone, in turn passing up to pale grey or white limestone' (Dunham \& Stubblefield, 1945). This had been described as 'Porcellanous Limestone' of Asbian $\left(\mathrm{D}_{1}\right)$ age by Hudson (1938) and may equate with such beds described by Anderson (1928) in Trollers Gill, although as discussed by Dunham \& Stubblefield (1945), it is not an accurate description of this succession. There is very limited exposure of this limestone and insufficient lithological distinction to justify recognition of a separate formation, and hence use of the term is discontinued in this study.

In the Greenhow Inlier, there is a marked reduction in grainsize in the Coldstones No. 4 Borehole (Fig. 8) above $295.2 \mathrm{~m}$, with a succession of fine-grained limestone, mainly medium grey below $250 \mathrm{~m}$ depth and mainly pale grey and thick-bedded or massive above, with few macrofossils other than subordinate beds with crinoid ossicles. This succession, previously considered the upper part of the Stump Cross Limestone (Strank, 1982b) is here attributed to the Cove Limestone Member. The uppermost $10 \mathrm{~m}$ (224.9-214.9 m depth) are coarse-grained and crinoidal, possibly reflecting the coarsening-upwards succession recorded in this member at Trollers Gill (Fig. 7).

The Cove Member in the Silverdale Borehole (Fig. 5) is $46 \mathrm{~m}$ thick (Murray, 1983) and is dominated by pale grey, fairly coarse-grained, grainstone and packstone with shelly fauna interbedded with rare fenestral lime-mudstones in the upper $15 \mathrm{~m}$, considered to be the Porcellanous Bed (Murray, 1983). Arthurton et al. (1988) recognised a conspicuous increase in the proportion of grainstones in the Horton in Ribblesdale area, coinciding with a thinning of the member and the presence of the Porcellanous Bed. The upper boundary of the member is repositioned relative to Murray (1983) above the upper lime-mudstone (EWJ1539) at the base of the overlying bed at $95.7 \mathrm{~m}$. The upper $6 \mathrm{~m}$ in this member $(102-95.7 \mathrm{~m})$ contains palaeokarstic surfaces which are not typical from this member at outcrop in the study area, but in the Settle district are thought to be associated with the Porcellanous Beds (Arthurton et al. 1988).

\section{2.c.2. Biostratigraphy}

Macrofossils: Little work has been done to establish the age of the Cove Limestone Member in Upper Wharfedale. Macrofauna are sparse, but concentrations of single species of corals and brachiopods including Axophyllum vaughani, Lithostrotion (=Siphonodendron) sociale, Syringopora sp., Linoprotonia ashfellensis and Megachonetes papilionaceous group were reported by Arthurton et al. (1988) from the Settle district. In the Skyreholme Inlier, Dunham \& Stubblefield (1945) recorded from the 'Hemitrypa Bed' the bryozoan Hemitrypa hibernica and alga Koninckopora inflata in association with Siphonodendron junceum, the last named fossil possibly indicating a late Asbian $\left(\mathrm{D}_{1}\right)$ age (see Poty, 1984; Mitchell, 1989). However, 
according to Nudds (1980) and Aretz \& Nudds (2005) S. junceum first appears in the early Asbian at Little Asby Scar farther north in the Stainmore Basin.

Microfossils: A restricted assemblage of foraminifers from the Gordale Scar section [3913 4640], consisting essentially of Archaediscus sp. (non 'angulatus' stage) and Koskinotextularia cribriformis, were interpreted as a deeper water Holkerian fauna by Arthurton et al. (1988). A typical Holkerian (shallow-water) assemblage was considered by Arthurton et al. (1988) to be present in the Silverdale Borehole, where diagnostic taxa included Archaediscus stilus, Holkeria daggeri, Nibelia (=Pojarkovella) nibelis, Palaeospiroplectammina paprothae and Septabrunsiina tynanti. However, in a reinvestigation of the borehole (Fig. 5, Table 4), the FAD of Endothyranopsis crassa (Fig. 4f) and Pseudoendothyra sublimis (EWJ1553) and Archaediscus karreri (EWJ1552) as well as common Neoarchaediscus (including N. stellatus), Koskinobigenerina sp. (Fig. 4j) and bilaminar Palaeotextularia, Omphalotis omphalota indicate late Asbian taxa in the lower part of the member, with the FAD of Bibradya inflata indicating a higher horizon of late Asbian age for the top of the member (EWJ1539).

At Conistone Dib, the lowermost beds (Pc4821) comprise the key foraminifers Archaediscus at angulatus stage (Fig. 3c), large A. ex gr. karreri, Koskinobigenerina sp., Neoarchaediscus stellatus and Pseudoendothyra sublimis (Fig. 7, Table 2), which suggest a late Asbian age

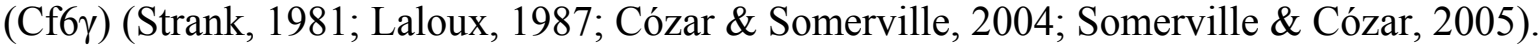
An additional late Asbian foraminiferal marker is Neoarchaediscus sp. (also from the lower beds, at Pc4822, Fig. 3e) and Endothyranopsis crassa from the upper part of the succession (Pc4830). The Neoarchaediscus Zone is regarded as largely equivalent to the Asbian and Brigantian substages (Conil et al. 1980, 1991; Riley, 1993; Jones \& Somerville, 1996), although true occluded forms, particularly $N$. stellatus, have never been illustrated in England below the late Asbian (e.g., Conil et al. 1980; Strank, 1981; Cózar \& Somerville, 2004), and they could be assigned to the problematic genera and subgenera Nodosarchaediscus, Asperodiscus or Nodasperodiscus.

In the Skyreholme Inlier, the basal sample (DMA320) at Trollers Gill (Figs $7 \&$ 9b) contains a limited foraminiferal assemblage, which only suggest an Asbian age (Table 3). However, 2 $\mathrm{m}$ higher in the succession (DMA321), an assemblage with the first occurrences of Cribrospira aff. panderi, Bibradya grandis, Neoarchaediscus stellatus, Palaeotextularia sp., Pseudoendothyra sublimis (Fig. 3q), and the algospongia Ungdarella uralica is assigned to

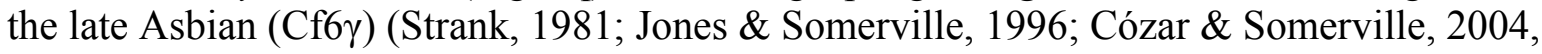
2005, 2013). The assemblages do not change significantly through the section, except for the youngest sample (DMA326), which contains the foraminifers Archaediscus ex gr. karreri and Cribrostomum lecomptei, also markers for the late Asbian (Conil et al. 1980; Cózar \& Somerville, 2004).

In Coldstones No. 4 Borehole (Fig. 8), Strank (1982b) recorded between 250 and $205 \mathrm{~m}$ a low-diversity foraminiferal assemblage of Archaediscus sp. and A. stilus and abundant alga Koninckopora inflata (Table 3) from the lower part of their Greenhow Limestone. Strank (1982b) noted the lack of diagnostic taxa, but considered the low diversity suggestive of a Holkerian age, although evidence for early Asbian taxa at greater depths in this borehole (see above) discounts this.

In summary, across the study area, strata mapped as the Cove Limestone Member are most probably late Asbian in age. This contrasts with the Holkerian age previously considered for 
the member, partly proposed from foraminiferal assemblages in the Silverdale Borehole (Fig. 5), east of Horton in Ribblesdale (Arthurton et al. 1988). Reinvestigation of this borehole suggests there is no evidence of a marked diachroneity within the member across the southern part of the Askrigg Block.

\section{2.d. Gordale Limestone Member (Malham Formation)}

\section{2.d.1 Lithostratigraphy}

The Gordale Limestone Member (upper part of the Malham Formation) is named after the type locality of Gordale Scar [3913 4640] (Fig. 1a), where the member is $94 \mathrm{~m}$ thick (Arthurton et al. 1988). This member also caps Malham Cove, where it forms a limestone pavement, a common feature of this member. It is typically medium-pale to very pale grey packstone/grainstone, well bedded, varying from thick- to very thick-bedded and its individual beds tend to form major scar features in the southern part of the district (Table 1).

The member is well represented at the head of Conistone Dib [39922 46821] with a 6 m-thick section of pale grey, very thick-bedded grainstone, with crinoid ossicles, micrite-coated intraclasts, brachiopod valves and rare Siphonodendron corals. The base of the member comprises a bioturbated intraclastic/crinoidal/packstone/grainstone with intraclasts $(>1 \mathrm{~mm}$ diameter), crinoids and peloids (Pc4832; Fig. 7). In the upper part of Conistone Dib [398771 467735], the basal bed of the Gordale Limestone rests with a small angular discordance on the underlying weakly bedded Cove Limestone.

At Threshfield Quarry, near Grassington (Fig. 1b), the succession comprises very thicklybedded, light grey, fine- to medium-grained, moderately sorted, intraclastic-skeletal-peloidal packstone. Bioclasts are dominated by crinoids with minor components of brachiopods. This quarry includes at least four prominent palaeokarstic surfaces (Fig. 10a) and had previously been assigned, erroneously, to the Cove Limestone Member (British Geological Survey, 1989).

\section{Insert Figure 10}

Above Linton Falls, Bow Bridge (RBH59; Fig. 1b) and 193 m east of Lythe House (RBH51), there is pale grey, well-bedded, medium-grained and poorly sorted skeletal-intraclasticpeloidal packstone. Bioclasts present at both localities include micritised crinoids and punctate brachiopods, with trilobites and coral fragments, including Syringopora (RBH59). Nearby, in the River Wharfe (RBH50) is a fine- to medium-grained peloidal-skeletal grainstone/floatstone (boundstone) with spar-filled cavities.

In the Skyreholme Inlier, above the gorge at Trollers Gill, the member comprises $c .50 \mathrm{~m}$ of thick and very thick tabular beds of wackestone, locally grainstone, extensively recrystallized to sparry calcite. No clear palaeokarstic surfaces are seen, but the top of the succession is marked by an unconformity, seen at Dibbles Bridge Quarry [405173 462958], where at least $1.3 \mathrm{~m}$ of cross-bedded grainstone composed of crinoids and brachiopod debris, along with small ooids, are truncated by the overlying Brigantian Hawes Limestone (Alston Formation (Fig. 7).

At Dry Gill, located immediately north of the North Craven Fault (Fig. 1b), there is a development of dark grey and cherty, fossiliferous, poorly sorted, medium- to coarse-grained grainstone/packstone (DMA327-8). Although previously designated the type locality of the Timpony Limestone (Dunham \& Stubblefield, 1945; Dunham \& Wilson, 1985, fig. 36), the 
coarse grain size is more typical of the Hargate End Limestone (Table 1), and is here attributed to be from the upper part of the Gordale Limestone Member.

In the Greenhow Inlier, the member is considered to equate with the upper part of the Greenhow Limestone and overlying Hargate End Limestone of Dunham \& Stubblefield (1945). At Coldstones Quarry (Figs 1b \& 10b), the basal beds comprise pale grey, mediumgrained, crinoidal-algal wackestone/packstone (WQ217) and fine- to medium-grained, crinoidal-algal-foraminiferal packstone /grainstone (WQ203). These are overlain by mediumgrained, moderately sorted, skeletal, crinoidal, algal and foraminifer-rich, packstone/ grainstone, locally with wackestone intraclasts, medium grey (WQ204-5) to pale grey (WQ206-7). The middle part of the face is a dominantly pale grey, intraclastic skeletal (crinoidal-algal-foraminiferal), medium-grained packstone (WQ218). Palaeokarstic surfaces, overlain by thin orange clays, are recognized throughout this succession (Fig. 8). There is evidence of deformation of the packstone/grainstone below, but not above, one such palaeokarstic surface (Fig. 10c). In the upper part of the quarry, the equivalent of the Hargate End Limestone is at least $20 \mathrm{~m}$ thick (Figs $8 \& 10 \mathrm{~b}$ ). The lower part comprises medium and pale grey, thickly but distinctively bedded, mottled, coarse-grained, poorly to moderately sorted intraclastic skeletal (crinoidal-algal) grainstone (WQ216). The uppermost c. $6 \mathrm{~m}$ comprise medium grey, medium- to thick-bedded, medium-grained, moderately sorted, skeletal packstone/grainstone/ rudstone (WQ215). The top of the formation occurs $4.5 \mathrm{~m}$ below the Girvanella Band; $3.5 \mathrm{~m}$ were recorded in Coldstones East Quarry (Dunham \& Stubblefield, 1945).

In Coldstones No. 4 Borehole (Fig. 8) the succession between depths of 214.9 and $77.71 \mathrm{~m}$ comprises pale grey to grey, very fine- and fine-grained, locally medium-grained, partially dolomitized limestone, with six grey-brown and yellow clay or mudstone beds. An incomplete succession from 77.71 to 49.94 m, equivalent to the Hargate End Limestone, comprises pale grey and medium grey, fine- and medium-grained limestone, locally crinoidal, and only distinguished from the underlying 'Greenhow Limestone' by the absence of clay interbeds.

At nearby Duck Street Quarry (Figs 1 b \& 8), the southern quarry comprises mainly pale grey, typically fine-grained and massive packstone at the upper and basal parts of the section, and medium-grained, moderately sorted intraclastic-skeletal-peloidal packstone/grainstone (Fig. 11a) with peloid wackestone intraclasts in the lower part and an isolated bed towards the top (WQ199). Three palaeokarstic surfaces are seen in the southern quarry (Figs 8 \& 11a). In the northern quarry a palaeokarstic surface with marked relief is underlain by a pale grey, upward coarsening, well sorted, trough and tabular cross-bedded, coarse- to very coarse-grained skeletal (crinoidal-algal) packstone/grainstone/ rudstone (WQ200), $1.5 \mathrm{~m}$ thick, underlain by fine-grained bioclastic packstone/grainstone with wave-ripple cross-lamination (Fig. 11b).

\section{Insert Fig. 11}

The Gordale Limestone Member in the Silverdale Borehole is $72 \mathrm{~m}$ thick (Murray, 1983) and show many similarities with the underlying Cove Limestone Member, being dominated by pale grey limestone with local fenestral lime-mudstone (Fig. 5). The Gordale Limestone is here more typically fine- to medium-grained wackestone to grainstones, on average finer than the Cove Limestone, and the presence of thin green clays (palaeosoils), pedotubules and Davidsonina septosa brachiopod biostromes (Fig. 5), however, are diagnostic of this member. 
Arthurton et al. (1988, fig. 13) recognized shale/mudstone horizons at eight levels in the Silverdale Borehole.

\section{2.d.2 Biostratigraphy}

Macrofossils: The Davidsonina (Cyrtina) septosa bands, marked by discrete concentrations of drifted brachiopods and corals, commonly with oncolitic coatings (Arthurton et al. 1988), occur predominantly within the Gordale Limestone Member in the southeast of the Askrigg Block. One such band was collected from Duck Street Quarry by Garwood \& Goodyear (1924) and was used to mark the base of the Hargate End Limestone by Dunham \& Stubblefield (1945). A further such band was recorded $\sim 25$ below the top of the Gordale Limestone Member in the Silverdale Borehole (Fig. 5).

At Threshfield Quarry (Figs. 1b \& 10a) (WMD16466-16482) the section includes the corals Dibunophyllum bipartitum, Palaeosmilia murchisoni and brachiopod Delepinea sp. The cooccurrence of Palaeosmilia murchisoni with Dibunophyllum bipartitum suggests an Asbian to basal Brigantian age. This locality is mentioned by Garwood \& Goodyear (1924) in the context of their Cyathophyllum murchisoni $\left(\mathrm{D}_{1}\right)$ Subzone. They state that the Cyrtinia septosa band (c. 25-30 m below the top of $\mathrm{D}_{1}$ ) is seen here, suggesting a late Asbian age.

At Coldstones Quarry (Fig. 8), macrofauna (WMD16563-16579) include the brachiopods Linoproductus/Linoprotonia sp., ?Linoprotonia hemisphaerica, Linoprotonia ashfellensis, ?Linoprotonia concinniformis, and ?Delepinea, and the coral Syringopora sp.. Dunham \& Wilson (1985) record common Linoprotonia spp. and L. hemisphaerica in early and late Asbian successions. Range plotting of faunal data provided in Garwood \& Goodyear (1924) shows that 'Productus' hemisphericus occurs at and above $\mathrm{D}_{1}$, which given its record below the Girvanella Band at Coldstones, indicates an Asbian age. ?Linoprotonia concinniformis is mainly of Brigantian age.

Hudson (1938, p. 311) considered the Dry Gill section as Holkerian (S2) strata. However, the diagnostic post-Holkerian coral Lithostrotion (= Siphonodendron) pauciradiale (Dunham \& Stubblefield, 1945) and Lithostrotion arachnoideum (Hudson, 1938) are recorded at the locality. Nudds (unpub. Ph.D. thesis, Univ. Durham, 1975) recorded the corals Lithostrotion vorticale and L. (= Siphonodendron) irregulare from this locality, of Holkerian-Asbian and Asbian-early Brigantian age, respectively (Nudds 1980). The brachiopods Antiquatonia?, Echinoconchus elegans, E. subelegans and Linoproductus? were found during this study (WMD16321-16358). Based on the known ranges of E. elegans, Antiquatonia? and the ranges of the corals identified by Nudds (unpub. Ph.D. thesis, Univ. Durham, 1975), an Asbian age seems most likely.

Microfossils: The key taxa are unequally distributed in the four studied outcrops in the west of the area (Table 2). At Threshfield Quarry (RBH4), assemblages include Protoinsolentitheca fundamenta, Eostaffella parastruvei, Pseudoendothyra sublimis,

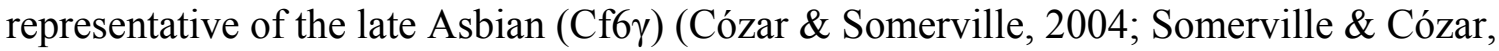
2005). The River Wharfe (RBH50), which contains primitive Neoarchaediscus, or in Wharfedale, 193 m east of Lythe House (RBH51), where Bibradya is recorded, are also markers of the late Asbian (Strank, 1981; Jones \& Somerville, 1996; Cózar \& Somerville, 2004). Above Linton Falls (RBH59) there is notable occurrence of Bradyina rotula, used as a marker of the latest Asbian (upper Cf6 $\gamma$ ) (Jones \& Somerville, 1996; Gallagher \& Somerville, 1997; Cózar \& Somerville, 2004). A similar transition from typical late to latest Asbian foraminiferal assemblages was recorded in the Gordale Limestone Member in the Feizor 
Borehole (BGS Registration number SD76NE9, southwestern Askrigg Block, Fig. 1a) by Cózar \& Somerville (2004).

At Coldstones Quarry (Fig. 8, Table 3), the basal sample (WQ217) includes the foraminifers Archaediscus at angulatus stage, Lituotubella magna, Omphalotis minima, Palaeotextularia sp. and algospongia Fasciella kizilia and Zidella maxima. From the overlying beds (WQ203), can be highlighted the occurrence of Neoarchaediscus stellatus, Neoarchaediscus sp., Omphalotis omphalota, Protoinsolentitheca fundamenta and Pseudoendothyra sublimis, all of them representative of the late Asbian (Cf6 $\gamma$ ) (Cózar \& Somerville, 2004; Somerville \& Cózar, 2005). In addition, Bibradya grandis (WQ205, Fig. 3s), Cribrostomum lecomptei (WQ206), and Endothyranopsis crassa (WQ207), also suggest a late Asbian age. Rich and diverse foraminiferal assemblages are recorded from near the top of the member (WQ215), highlighted by the occurrence of Archaediscus chernoussovensis, A. ex gr. karreri, $A . k$. karreri, Bradyina rotula, Cribrospira panderi (Fig. 3r), Endostaffella delicata, E. fucoides, Endothyranopsis crassa, Eostaffella mosquensis, Neoarchaediscus spp., Protoinsolentitheca fundamenta and Pseudoendothyra sublimis. This assemblage can be assigned to the latest

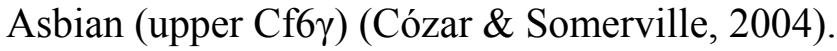

Above a depth of $204 \mathrm{~m}$ in Coldstones No. 4 Borehole (Fig. 8), Strank (1982b) recorded a much richer and diverse foraminiferal assemblage including Archaediscus enormis, $A$. karreri, A. grandiculus, Cribrostomum longiseptata ( $=$ C. lecomptei), Cribrostomum spp., Palaeotextularia longiseptata, Pseudoendothyra sublimis, Vissariotaxis cf. compressa and Endothyranopsis crassa (Table 3). Strank (1982b) assigned an Asbian age for these taxa, but they are also respresentative of the late Asbian (Conil et al. 1980; Cózar \& Somerville, 2004; Somerville \& Cózar, 2005). At Duck Street South Quarry (WQ199) and North Quarry (WQ200) (Fig. 8; Table 3) the more significant foraminifers include Cribrostomum spp., $C$. lecomptei, Endothyranopsis aff. crassa, Eostaffella ex gr. parastruvei, Neoarchaediscus stellatus, Protoinsolentitheca fundamenta and algospongia Ungdarella uralica, allowing an

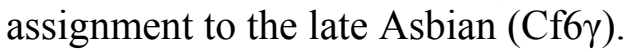

Important foraminifers from Dry Gill, recorded by Strank (1982a) include Archaediscus at angulatus stage, A. krestovnikovi, Endothyranopsis crassa, Nodosarchaediscus sp. and Omphalotis minima. Strank (1982a) considered this assemblage to represent a Holkerian or possibly early Asbian age, although it is more typically represented in the late Asbian (Conil et al. 1980; Jones \& Somerville, 1996). Samples collected for this study (DMA327-8) contain Archaediscus at angulatus stage, A. ex gr. karreri, A. karreri grandis, Loeblichiidae, Neoarchaediscus stellatus, Protoinsolentitheca fundamenta, Palaeotextularia spp., and the algospongia Stacheoides tenuis, Ungdarella uralica and Zidella maxima (Table 3), which is consistent with a late Asbian age (Cf6y) (Cózar \& Somerville, 2004). Such an age, along with the distinct lithology, is more consistent with the upper part of the Gordale Limestone Member.

In the Silverdale Borehole (Fig. 5, Table 4), the FADs of taxa characteristic of the late Asbian, e.g. Cribrostomum lecomptei (EWJ1534, Fig. 4b) and Palaeotextularia longiseptata (EWJ1529), Cribrospira panderi (EWJ1521) appear in higher beds in the Gordale Limestone Member. The FADs of important algae include Ungdarella uralica (EWJ1526) and Koninckopora sp. B (EWJ1531). The FAD of Bradyina rotula (Fig. 41) (EWJ1515) and Parajanischewskina brigantiensis (EWJ1514, Fig. 4i) in the uppermost $7 \mathrm{~m}$ of the member suggests proximity to the latest Asbian/Brigantian boundary. 
In summary, foraminiferal assemblages suggest a late Asbian age for the Gordale Limestone Member. This is in agreement with observed brachiopod/coral assemblages and is consistent with previous interpretations for this member (Table 1). The base of the member starts close to the lower part of the late Asbian. A latest Asbian age is recognized locally, especially in the Greenhow Inlier within the former Hargate End Limestone and in the Silverdale Borehole.

\section{2.e. Summary of rationalized lithostratigraphy}

The Chapel House Limestone Formation is recognised in several boreholes, notably in the type locality and also in this study at Silverdale, approximately $5 \mathrm{~km}$ north of the North Craven Fault. The formation thins rapidly northwards across the Craven Fault system. The very shallow-water lime-mudstones developed at the top of the formation are distinct from any facies present within the overlying Kilnsey Formation. The current study of foraminifers and algae in the Silverdale support the previously published interpretation of an Arundian age for the formation, although constrained here to be late Arundian in the Silverdale Borehole (Fig. 5). This is considered to reflect northward progradation onto the Askrigg tilt-block high, with only younger components of the Chapel House Limestone Formation in the northern setting.

The Kilnsey Formation is only unequivocally recognized in the study area in Upper Wharfedale, notably at the type locality of Kilnsey Crag. The darker grey and more argillaceous nature of the formation provides a suitable lithological distinction from the overlying paler grey and purer limestone of the Malham Formation. The presence of two members within the Kilnsey Formation is also confirmed. Existing published information, mainly based upon coral/brachiopod assemblages (Arthurton et al. 1988), indicated Arundian and Holkerian ages, respectively, for the Scaleber Force Limestone and Scaleber Quarry Limestone members. This contrasts with the current study, from which foraminiferal/ algal assemblages suggest late Holkerian and early Asbian ages, respectively, for the uppermost parts of the two members (Fig. 2). Passing north of the North Craven Fault, the Kilnsey Formation thins dramatically and in the Silverdale Borehole only the upper member is present, the base of the Scaleber Quarry Limestone Member coinciding with the incoming of Holkerian taxa and with early Asbian foraminifers recorded within the upper part of the formation, with the topmost bed of late Asbian age.

It is concluded that there is no justification for retaining the Timpony Limestone of the Skyreholme Inlier as a lithostratigraphical term. The two main outcrop localities in areas defined by Dunham \& Stubblefield (1945) and in the Coldstones No. 4 Borehole (Strank, 1982b; Dunham \& Wilson, 1985) relate to three distinct units. The lower part of the borehole is lithologically similar to the Scaleber Quarry Limestone Member, with foraminiferal/algal assemblages suggesting a comparable early Asbian age (Fig. 2).

Carbonates of Holkerian or older age have not been proved within the Greenhow and Skyreholme inliers. No boreholes penetrate to pre-Carboniferous basement, precluding any interpretation as to whether pre-Asbian carbonates were deposited on this part of the tiltblock high. It is possible that the southern margin of the block was an emergent palaeogeographical high during the Arundian to early Holkerian with no limestone deposition. In support of this, the late Arundian to Holkerian basinal succession within the Skipton Anticline present immediately to the south, is dominated by dark grey calcareous mudstone of the Hodder Mudstone Formation and lacks the thicker carbonate turbidites seen 
during the earliest Arundian (Embsay Limestone Member) and Asbian (Pendleside Limestone Formation) of the Craven Group (Fig. 2).

The mainly massive character of the Cove Limestone Member is thought to be distinctive. Successions in the Silverdale Borehole (Fig. 5) and at Conistone Dib and Trollers Gill (Fig. 7) are consistently of late Asbian age, significantly younger than the late Holkerian typically attributed to the member in the Settle area (Fig. 2). In the Greenhow Inlier, the member is recognized in the Coldstones No. 4 Borehole (Fig. 8), corresponding with the upper part of the Stump Cross Limestone of previous interpretations. The porcellanous lime-mudstone beds distinctive elsewhere on the Askrigg Block appear to be absent in the upper part of the member in the study area, but are recognized farther north on the Askrigg Block in the Silverdale Borehole.

Support for diachroneity of the Cove Limestone may be found in the Furness district of south Cumbria, where its lithological equivalent is the Park Limestone, with the overlying Gordale Limestone represented by the Urswick Limestone. In Furness, the stratotype section for the Holkerian is designated at Barker Scar [SD 3330 7827], where the base of the Holkerian is placed $4.2 \mathrm{~m}$ above the base of the Park Limestone Formation, based on macrofossil evidence (Rose \& Dunham, 1977; Ramsbottom, 1981; Johnson et al., 2001; Waters, 2011). The presence of a significant non-sequence in the stratotype section (Riley, 1993) equates temporally with the significant non-sequence between the Chapel House Limestone and Kilnsey formations on the southern part of the Askrigg Block (see section 3.a).

The Gordale Limestone Member is typically well-bedded, forming prominent scars and limestone pavements and contains well-developed palaeokarstic surfaces. The member is entirely late Asbian in age, refined from the Asbian age previously recognized (Fig. 2). A distinct well-bedded, dark-pale interbedded facies, formerly recognized as the Hargate End Limestone, is locally present in the upper part of the member in the Greenhow Inlier.

\section{Discussion: controls on the deposition of the Great Scar Limestone Group 3.a. Environments of deposition}

The Great Scar Limestone Group was deposited in a shallow-marine environment developed upon a persistently elevated Askrigg Block. The Chapel House Limestone Formation represents an Arundian onlap of shallow-marine conditions (Fig. 12), evidenced by basal ooidal grainstones and subsequent intertidal-supratidal deposits, shown by lime-mudstone with fenestral fabrics, onto an emergent Askrigg Block. This late Arundian regressive phase is followed by Holkerian transgression and renewed onlap of carbonates onto the Askrigg Block, this time by the Kilnsey Formation (Fig. 12). An equivalent regressive phase at the end of the Arundian is evident in South Wales-Bristol (Wright \& Vanstone, 2001), suggesting it results from a low-frequency-high amplitude sea-level fall, rather than tectonic uplift. The Kilnsey Formation is interpreted as carbonate ramp deposits, pre-dating development of the Cracoean reefs that flank the southern margin of the Askrigg Block (Fig. 12). The parallel laminated, argillaceous kamaenid packstones of the Scaleber Force Limestone Member are interpreted as comparatively deep-water shelf deposits present in the vicinity of the Craven Fault System. The upward-coarsening transition to the less argillaceous, fine- to coarse-grained, bioclastic packstone or grainstone of the Scaleber Quarry Limestone Member is interpreted as reflecting an upward-shoaling succession, which progrades further north onto the Askrigg Block, being the only component of the formation evident in the Silverdale Borehole (Fig. 12). 


\section{Insert Fig. 12}

The relatively homogeneous, massive, coarsely bioclastic, peloidal Cove Limestone Member with uncommon discernible macrofauna and low-diversity foraminiferal assemblages, may represent a partially restricted lagoonal environment behind the apron reef. In the study area, the member comprises an upward-coarsening succession considered typical of deposits within an upward-shoaling shallow-shelf, subtidal to intertidal environment. Fenestral porcellanous (micritic) lime-mudstone bands, common in the upper part of the member within condensed successions north of the immediate footwall of the North Craven Fault (Arthurton et al. 1988), are probably associated with hypersaline lagoon conditions during regression and periodic emergence (Fig. 12). Their absence in the study area may reflect enhanced subsidence rates along the southern flank of the Askrigg Block during a late Asbian phase of tectonic activity along the Craven Fault System.

The Gordale Limestone Member occurs in a similar shallow-water shelfal environment, but more abundant and diverse macrofauna and microfauna attest to more open circulation. The local development of cross-bedded crinoidal grainstones suggests intermittent influx of bioclastic material associated with strong traction currents. Periodic subaerial emergence in this member is attested by the presence of palaeokarstic surfaces associated with palaeosoils. An unusual facies, formerly referred to as the Hargate End Limestone, occurs in the upper part of the member between the northern and southern components of the North Craven Fault (Fig. 1b), where the member is thickest (see below). The combination of darker grainstone/packstone and presence of cherts, particularly evident at Dry Gill, may suggest enhanced subsidence within this fault block during latest Asbian times.

\section{3.b. Thickness variations related to tectonism}

The Askrigg Block is modelled as a tilt-block with an abrupt southern margin bounded by the Craven Fault System and increased subsidence rates northwards towards the Stainmore Trough. Through comparison of the Raydale and Beckermonds Scar boreholes (Fig. 1a) a clear southward onlap of the tilt-block is evident, with successively older Carboniferous strata recorded to the north (Dunham \& Wilson, 1985, fig.4; Aitkenhead et al. 2002, fig. 11). Comparison of the thickness of the late Asbian strata including the Danny Bridge Limestone Formation in the Beckermonds Scar and Raydale boreholes and River Clough to Nor Gill sections (see Dunham \& Wilson, 1985, fig. 5, columns 1, 4, 5, 6 \& 7) and the Malham Formation in the south shows the thinnest and most condensed development in the area immediately north of the North Craven Fault in the southwest of the Askrigg Block (Fig. 13).

\section{Insert Fig. 13}

In the footwall of the North Craven Fault, the Malham Formation shows a marked thickening towards the east, ranging from $115 \mathrm{~m}$ in the southwest at Twistleton Scars (Arthurton et al. 1988) to $>245 \mathrm{~m}$ in the southeast in Coldstones No.4 Borehole (Fig. 13). The transition, mostly accounted for by a thickening of the Gordale Limestone Member, suggests the Askrigg Block had a component of increased eastward, as well as northward, subsidence rates during the late Asbian. It would appear that the Coldstones Quarry and Coldstones No. 4 Borehole, despite being located immediately north of the master North Craven Fault, underwent rapid subsidence. A northern splay of the fault, with a net downthrow to the north at crop, may have controlled subsidence during the late Asbian. 
In the Settle area, Arthurton et al. (1988, figs 12 \& 13) noted the increased thickness of the Kilnsey and Malham formations in the hangingwall of the North Craven Fault and again south of the Middle Craven Fault. This appears to form a series of fault-controlled terraces with enhanced subsidence rates to the south. It is feasible that the onset of this subsidence in the late Asbian was the controlling factor for the transition of the carbonate ramp into a reefrimmed shelf.

\section{3.c. Evidence for cyclicity}

The poor development of bedding and general absence of palaeokarstic surfaces in the Cove Limestone Member is inferred to indicate that either sea-levels were not fluctuating rapidly during the early part of the late Asbian or that deposition occurred at depths greater than the sea-level range. In contrast, Schwarzacher (1958) recognized nine cycles within the overlying Gordale Limestone Member, bounded by 'master bedding planes'. These cycles provide the stepped scar topography distinctive of this member. Mudstone (shale) beds, present in the member, may be laterally persistent and range from a few centimetres to $>2 \mathrm{~m}$ thickness. They formed by slow accumulation of a limited supply of clastic debris entering the otherwise carbonate-dominated depositional basin during pauses or reductions in limestone deposition, indicating periodic temporary emergence (Waltham, 1971) related to minor depositional cyclicity. The thicker mudstones tend to occur above palaeokarstic surfaces (e.g., Fig. 10c). They may include bentonite-rich clays, derived mainly as airborne fallout from distant explosive volcanicity, resembling, but less abundant than, Derbyshire's 'clay wayboards' (Walkden, 1972). In North Wales similar beds were considered by Somerville (1979) to be residual soils or palaeosoils derived from subaerial alteration of wind-blown volcanic debris. There is evidence of fracturing of the limestone below, but not above, some palaeokarstic surfaces (Fig. 10c), suggesting that some emergence is in response to tectonic uplift in the footwall of the North Craven Fault, although no angular discordances are recognized within this member. However, the regular development of palaeokarstic surfaces suggests repeated shallowing and emergence - a reflection of glacio-eustatic sea-level oscillations. The onset of glacio-eustasy in this region during late Asbian times is slightly later than the Asbian age proposed in the South Wales - Bristol area by Wright \& Vanstone (2001).

Ramsbottom (1973) considered the early Asbian succession (the lower part of his fifth mesothem), which commonly contains abundant Daviesiella llangollensis, to be absent across the Askrigg Block, suggesting a prominent non-sequence coincident with a major lowstand developed at this time. However, the current study recognizes strata of this age within the Scaleber Quarry Limestone. A sixth mesothem was considered to coincide with the base of the Brigantian (Ramsbottom, 1973). Evidence for this is seen with development of a lowangle unconformity at the top of the Gordale Limestone Member at the head of Trollers Gill (Fig. 7) and at Coldstones Quarry. A further unconformity is locally recognized between the Cove Limestone and Gordale Limestone members in Conistone Dib. This suggests a component of structural influence, perhaps tilting of the Askrigg Block, has also influenced development of these unconformities. This may, in part, account for the thinning of the Asbian succession seen over the tilt-block high (Fig. 13).

\section{Conclusions}

A single rationalized lithostratigraphy for the Great Scar Limestone Group is demonstrated along the southern flank of the Askrigg Block. Analysis of foraminiferal/algal assemblages suggests that component formations and members have age ranges significantly younger than previously reported. In the Kilnsey Formation, the Scaleber Force Limestone Member is of 
Holkerian age (formerly Arundian) and the Scaleber Quarry Limestone Member is mainly early Asbian in age (formerly early Holkerian). In the Malham Formation, the Cove Limestone Member is late Asbian (formerly late Holkerian), whereas the Gordale Limestone Member is late Asbian (formerly early - late Asbian). Both the Arundian and Holkerian successions show evidence of marked northward progradation onto the Askrigg Block, which formed a palaeotopographical high at these times, but comprise upward-shoaling successions. The end Arundian regressive phase is considered to be a consequence of a low-frequencyhigh-amplitude sea-level fall, rather than tectonic controls. The earliest late Asbian succession of the Cove Limestone Member shows a further upward-shoaling succession, which on the high of the Askrigg Block is evidenced by development of microbial limemudstone and culminates in development of a low-angle unconformity. Cyclic sedimentation patterns are first recognised in the Gordale Limestone Member and suggest the onset of glacio-eustatic sea-level oscillations affecting this region during late Asbian times. However, superimposed upon these high-frequency base-level fluctuations, facies variations indicate a phase of tectonically-induced subsidence along the margins of the Craven Fault System during deposition of the upper part of the Gordale Limestone, capped by a further low-angle unconformity at the base of the Brigantian Hawes Limestone Member. This subsidence appears to be greatest in the east, in the Greenhow area, associated with more than doubling of the thickness of the Malham Formation. This phase of subsidence, coincides with and may be the cause of the transition from carbonate ramp to a reef-rimmed shelf.

\section{Acknowledgements}

Shirley Everett (Hanson Aggregates) is thanked for providing access to Coldstones Quarry, and permitting publication of relevant data. Land owners and Natural England are thanked for their permissions to access and collect specimens. The help of Neil Aitkenhead and Iain Burgess, introducing the lead author to the carbonate geology of the area, is greatly appreciated. Brian D. Keith and an anonymous referee are thanked for their constructive reviews. We thank Andy Farrant for his helpful comments on the manuscript. Fieldwork for PC and IS was funded by the project CGL2012-30922BTE. Photos in figures 6, 9, 10, 11 taken by $\mathrm{CW}$ unless otherwise indicated and reproduced with the permission of the Director, British Geological Survey, C NERC. CW, RH, DM and MW publish with the approval of the

Executive Director, British Geological Survey, Natural Environment Research Council. The work was funded by the Geology and Regional Geophysics Directorate, BGS.

\section{Declaration of Interest}

None.

\section{References}

Aitkenhead, N., Barclay, W. J., Brandon, A., Chadwick, R. A., Chisholm, J. I., Cooper, A. H. \& Johnson, E. W. (eds) 2002. British regional geology: The Pennines and adjacent areas. HMSO (for the British Geological Survey), London.

Anderson, F. W. 1928. The Lower Carboniferous of the Skyreholme Anticline, Yorkshire. Geological Magazine 65, 518-527.

Aretz, M. \& Nudds, J. R. 2005. The coral fauna of the Holkerian/Asbian boundary stratotype section (Carboniferous) at Little Asby Scar (Cumbria, England) and its implications for the boundary. Stratigraphy 2, 167-190. 
Arthurton, R. S., Johnson, E. W. \& Mundy, D. J. C. 1988. Geology of the country around Settle. Memoir of the British Geological Survey, Sheet 60 (England \& Wales).

British Geological Survey, 1989. Settle, England and Wales Sheet 60. Bedrock. (Keyworth, Nottingham: British Geological Survey).

Conil, R., Groessens, E., Laloux, M., Poty, E. \& Tourneur, F. 1991. Carboniferous guide foraminifera, corals and conodonts in the Franco-Belgian and Campine basins. Their potential for widespread correlation. Courier Forschungs-Institut Senckenberg 130, 15-30.

Conil, R., Longerstaey, P. J. \& Ramsbottom, W. H. C. 1980. Matériaux pour l'étude micropaléontologique du Dinantien de Grande-Bretagne. Mémoires de l'Institut de Géologie de l'Université de Louvain 30, 1-187.

Cossey, P. J, Adams. A. E, Purnell, M. A, Whiteley, M. J., Whyte, M. A. \& Wright, V. P. 2004. British Lower Carboniferous Stratigraphy. Geological Conservation Review Series, 29. Joint Nature Conservation Committee, Peterborough.

Cózar, P. \& Somerville, I. D. 2004. New algal and foraminiferal assemblages and evidence for recognition of the Asbian-Brigantian boundary in northern England. Proceedings of the Yorkshire Geological Society 55, 43-65.

Cózar, P. \& Somerville, I.D. 2005. Late Viséan calcareous algal assemblages in south eastern Ireland. Neues Jahrbuch für Geologie und Paläontologie, Mh., 2005(2), 95-117.

Cózar, P. \& Somerville, I.D. 2013. The Carboniferous Archerbeck Borehole, near Canonbie (Dumfriesshire, southern Scotland): biostratigraphic revision of the late Asbian to early Pendleian succession using foraminiferans and regional correlations. Earth and Environmental Science, Transactions of the Royal Society of Edinburgh, 103, 105-122.

Dean, M. T., Browne, M. A. E., Waters, C. N. \& Powell, J. H. 2011. A lithostratigraphical framework for the Carboniferous successions of Northern Great Britain (onshore). British Geological Survey Research Report, RR/10/07, 174pp.

Dunham, K.C. \& Stubblefield, C.J. 1945. The stratigraphy, structure and mineralisation of the Greenhow mining area, Yorkshire. Quarterly Journal of the Geological Society of London 100, 209-268.

Dunham, K. C. \& Wilson, A. A. 1985. Geology of the Northern Pennine Orefield: Volume 2: Stainmore to Craven. Memoir of the British Geological Survey, sheets 40, 41 and 50, and parts of 31, 32, 51, 60 and 61 (England \& Wales). HMSO, London.

Gallagher, S. J. \& Somerville, I. D. 1997. Late Dinantian (Lower Carboniferous) platform carbonate stratigraphy of the Buttevant area, North Co. Cork. Geological Journal 32, 313315.

Garwood, E. J. \& Goodyear, E. 1924. The Lower Carboniferous succession in the Settle district and along the Line of the Craven Faults. Proceedings of the Geologists' Association 80, 184-314.

George, T. N., Johnson, G. A. L., Mitchell, M., Prentice, J. E., Ramsbottom, W. H. C., Sevastopulo, G. D. \& Wilson, R. B. 1976. A correlation of Dinantian rocks in the British Isles. Geological Society, London, Special Report 7, 87pp. 
Hudson, R. G. S. 1938. The Carboniferous Rocks. In: The geology of the country around Harrogate. Proceedings of the Geologist's Association 49 (3), 306-330.

Johnson, E. W., Soper, N. J. \& Burgess, I. C. 2001. Geology of the country around Ulverston. Memoir of the British Geological Survey, Sheet 48 (England and Wales).

Jones, G. Ll. \& Somerville, I. D. 1996. Irish Dinantian biostratigraphy: practical applications. In Recent Advances in Lower Carboniferous Geology (eds P. Strogen, I. D. Somerville \& G. Ll. Jones). pp. 371-385. Geological Society Special Publication no. 107.

Laloux, M. 1987. Foraminifères du Viséen Supérieur et du Namurien du Bassin franco-belge. Bulletin de la Société belge de Géologie 96, 205-220.

Lowe, D. J. \& Waters, C. N. 2014. Geological influences on cave origin and development in the Yorkshire Dales, UK. Cave and Karst Science 41 (1) 13-35.

Mitchell, M. 1989. Biostratigraphy of Viséan (Dinantian) rugose coral faunas from Britain. Proceedings of the Yorkshire Geological Society 47, 233-247.

Murray, D. W. 1983. The limestone and dolomite resources of the country around Settle and Malham, North Yorkshire (with notes on the hard-rock resources of the Horton-inRibblesdale area). Description of parts of geological sheets 50 and 60. Mineral Assessment Report of the Institute of Geological Sciences 126, $31 \mathrm{pp}$.

Nudds, J. R. 1980. An illustrated key to the British Lithostrotionid corals. Acta Palaeontologica Polonica 25, 385-394.

Nudds, J. R. \& Somerville, I. D. 1987. Two new species of Siphonodendron (Rugosa) from the Viséan of the British Isles. Proceedings of the Yorkshire Geological Society 46, 293-300.

Poty, E. 1984. An evolutionary pattern for the Western European Lithostrotionidae.

Palaeontographica Americana 54, 465-469.

Ramsbottom, W. H. C. 1973. Transgressions and regressions in the Dinantian: a new synthesis of British Dinantian stratigraphy. Proceedings of the Yorkshire Geological Society 39, 567-607.

Ramsbottom, W. H. C. 1974. Dinantian. In The Geology and Mineral Resources of Yorkshire (eds D. H. Rayner \& J. E. Hemingway). pp. 47-73. Occasional Publication of the Yorkshire Geological Society.

Ramsbottom, W. H. C. 1981. Fieldguide to the boundary stratotypes of the Carboniferous stages in Britain. Biennial Meeting of the Subcommisson of Carboniferous Stratigraphy, Leeds.

Riley, N. J. 1993. Dinantian (Lower Carboniferous) biostratigraphy and chronostratigraphy in the British Isles. Journal of the Geological Society of London 150, 427-446.

Rose, W. C. C. \& Dunham, K. C. 1977. Geology and Hematite deposits of South Cumbria. Economic Memoir of the Geological Survey of Great Britain, Sheets 58 and part of 48.

Schwarzacher, W. 1958. The stratification of the Great Scar Limestone in the Settle district of Yorkshire. Liverpool and Manchester Geological Journal 2, 124-142. 
Somerville, I. D. 1979. Minor sedimentary cyclicity in late Asbian (Upper D1) limestones in the Llangollen district of North Wales. Proceedings of the Yorkshire Geological Society 42, 317-341.

Somerville, I. D. \& Cózar, P. 2005. Late Asbian to Brigantian (Mississippian) foraminifera from south-east Ireland: Comparison with Northern England assemblages. Journal of Micropalaeontology 24, 131-142.

Strank A. R. E. 1981. Foraminiferal biostratigraphy of the Holkerian, Asbian and Brigantian stages of the British Lower Carboniferous. Unpublished PhD thesis, University of Manchester, $391 \mathrm{pp}$.

Strank, A. R. E. 1982a. Foraminifera from the Timpony Limestone, Greenhow, Yorkshire. IGS Palaeontological Unit Report PDL 82/196.

Strank, A. R. E. 1982b. Foraminifera from the Coldstones No. 4 Borehole. IGS Palaeontological Unit Report PDL 82/156.

Strank, A. R. E. 1982c. Foraminifera from the Coldstones No. 4 Borehole. IGS Palaeontological Unit Report PDL 82/166.

Vachard, D. \& Cózar, P. 2010. An attempt of classification of the Palaeozoic incertae sedis Algospongia. Revista Española de Micropaleontología 42 (2), 129-241.

Walkden, G. M. 1972. The mineralogy and origin of interbedded clay wayboards in the Lower Carboniferous of the Derbyshire Dome. Geological Journal 8, 143-160.

Waltham, A. C. 1971. Shale units in the Great Scar Limestone of the southern Askrigg Block, Proceedings of the Yorkshire Geological Society 38, 285-292.

Waters, C. N. 2011. Chapter 2. Definitions of chronostratigraphic subdivisions: geochronology and event stratigraphy. In: A revised correlation of Carboniferous rocks in the British Isles. Waters, C.N., Somerville, I.D., Jones, N.S., et al., The Geological Society, London, Special Report 26, 3-10.

Waters, C. N., Waters, R. A., Barclay, W. J., \& Davies, J. R. 2009. A lithostratigraphical framework for the Carboniferous successions of southern Great Britain (Onshore). British Geological Survey Research Report, RR/09/01.

Waters, C. N. \& Davies, S. J. 2006. Carboniferous: extensional basins, advancing deltas and coal swamps. In: The Geology of England and Wales. (eds P. J. Brenchley \& P. F. Rawson). pp. 173-223. The Geological Society of London. Second Edition.

Waters, C. N. \& Lowe, D. J. 2013. Chapter 2: Geology of the limestones. In Caves and Karst of the Yorkshire Dales (eds T. Waltham \& D. Lowe). pp. 11-28. British Cave Research Association, no. 1.

Wilson, R. B. 1989. A study of the Dinantian marine macrofossils of central Scotland. Transactions of the Royal Society of Edinburgh: Earth Sciences 80, 91-126.

Wright, V. P. \& Vanstone, S. D. 2001. Onset of Late Palaeozoic glacio-eustasy and the evolving climates of low latitude areas: a synthesis of current understanding. Journal of the Geological Society, London 158. 579-582. 


\section{Figures}
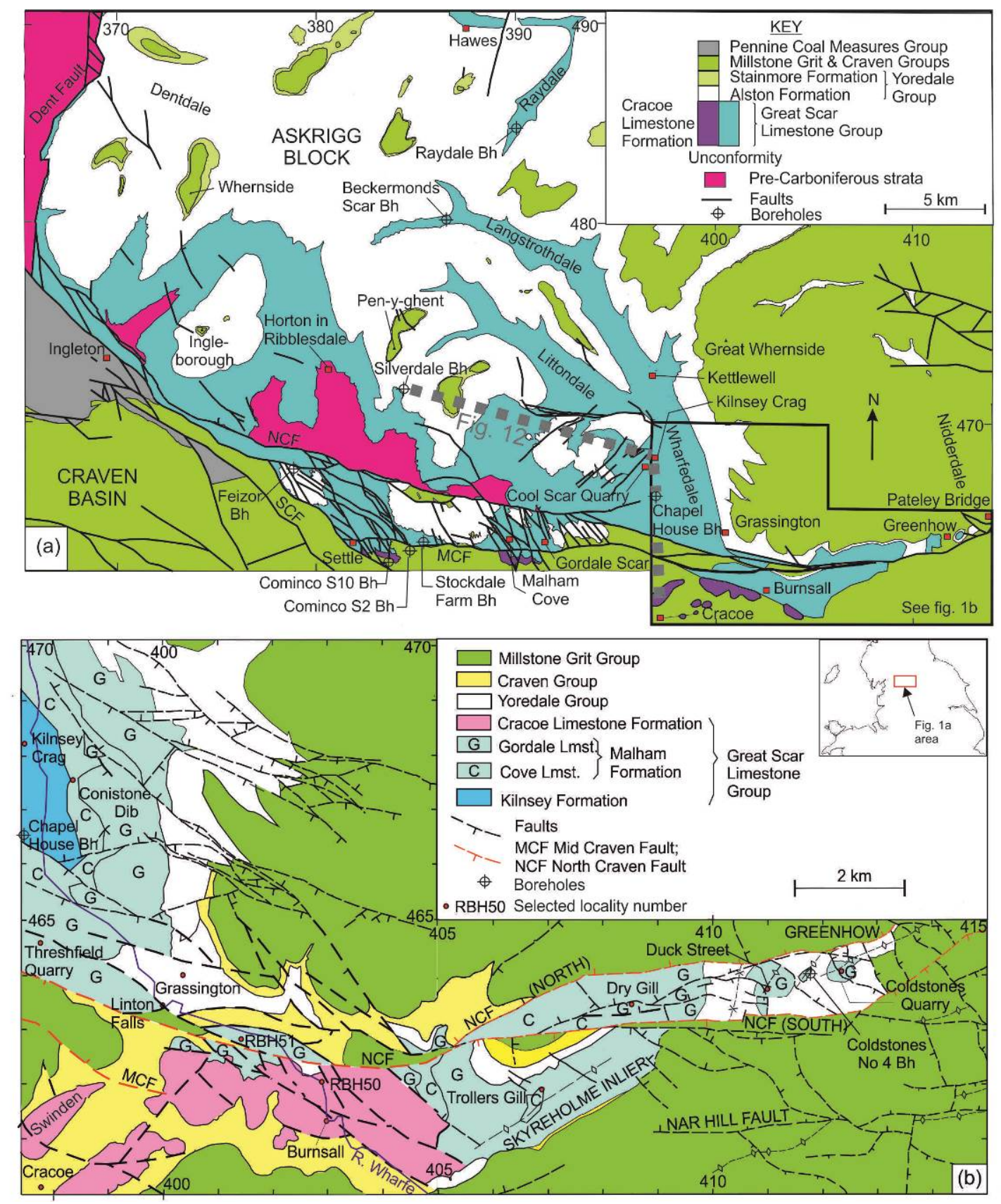

Figure 1. (a) Geological map showing the distribution of the Great Scar Limestone Group across the southern part of the Askrigg Block (based upon Waters and Lowe, 2013, fig. 2.3 and 2.8). (b) Geological map of the Great Scar Limestone Group inliers located between Grassington and Pateley Bridge (sourced from BGS revision mapping in 2011-2014). Map coordinates: British National Grid. British Geological Survey (C) NERC 2015. All rights Reserved. 


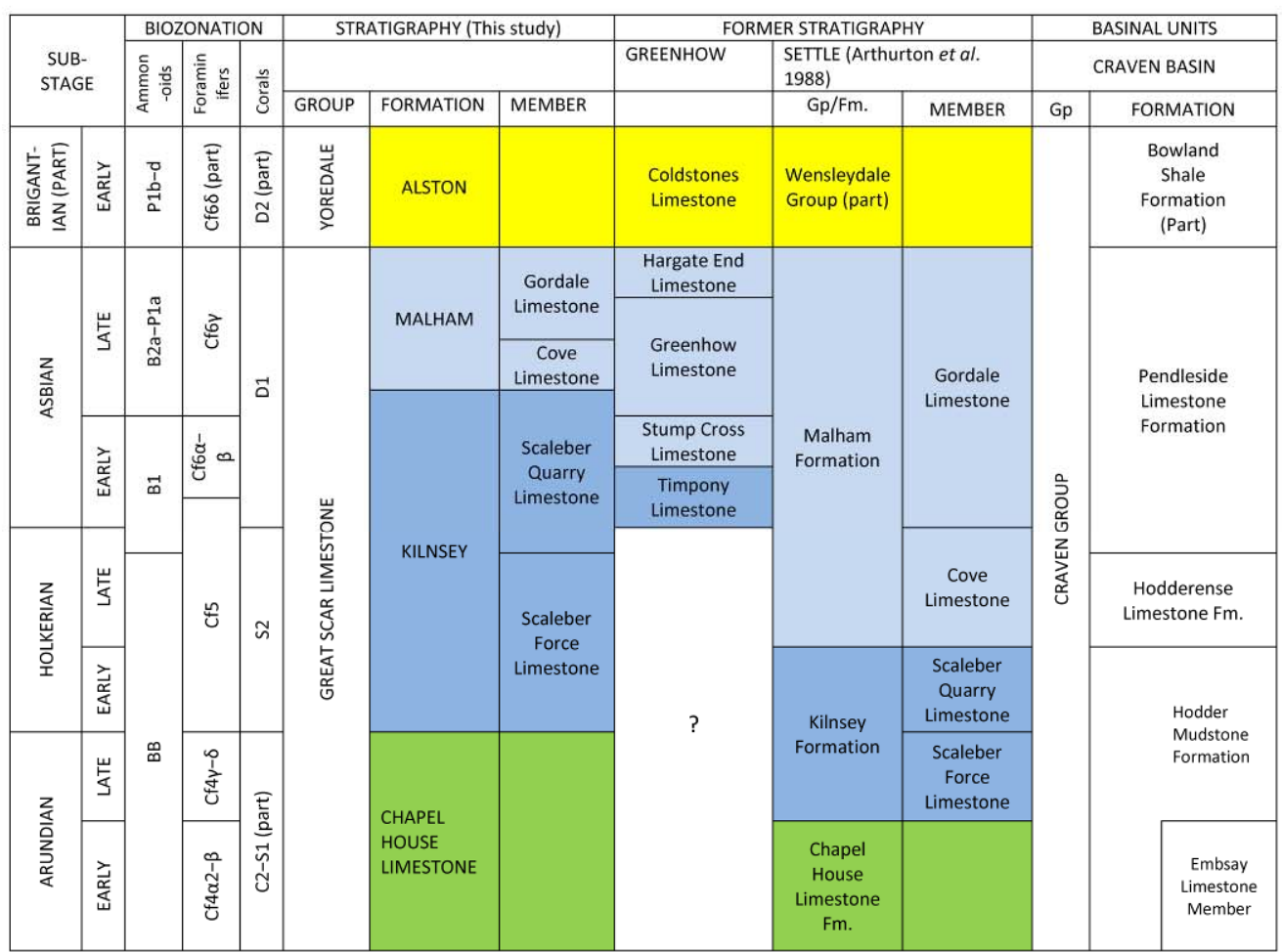

Figure 2. (Colour online) Revised biostratigraphical ages for the Great Scar Limestone Group within the study area. Former nomenclature for the Greenhow Inlier is based upon Dunham \& Wilson (1985). Basinal succession of the Craven Basin is based upon Waters et al. (2009). 


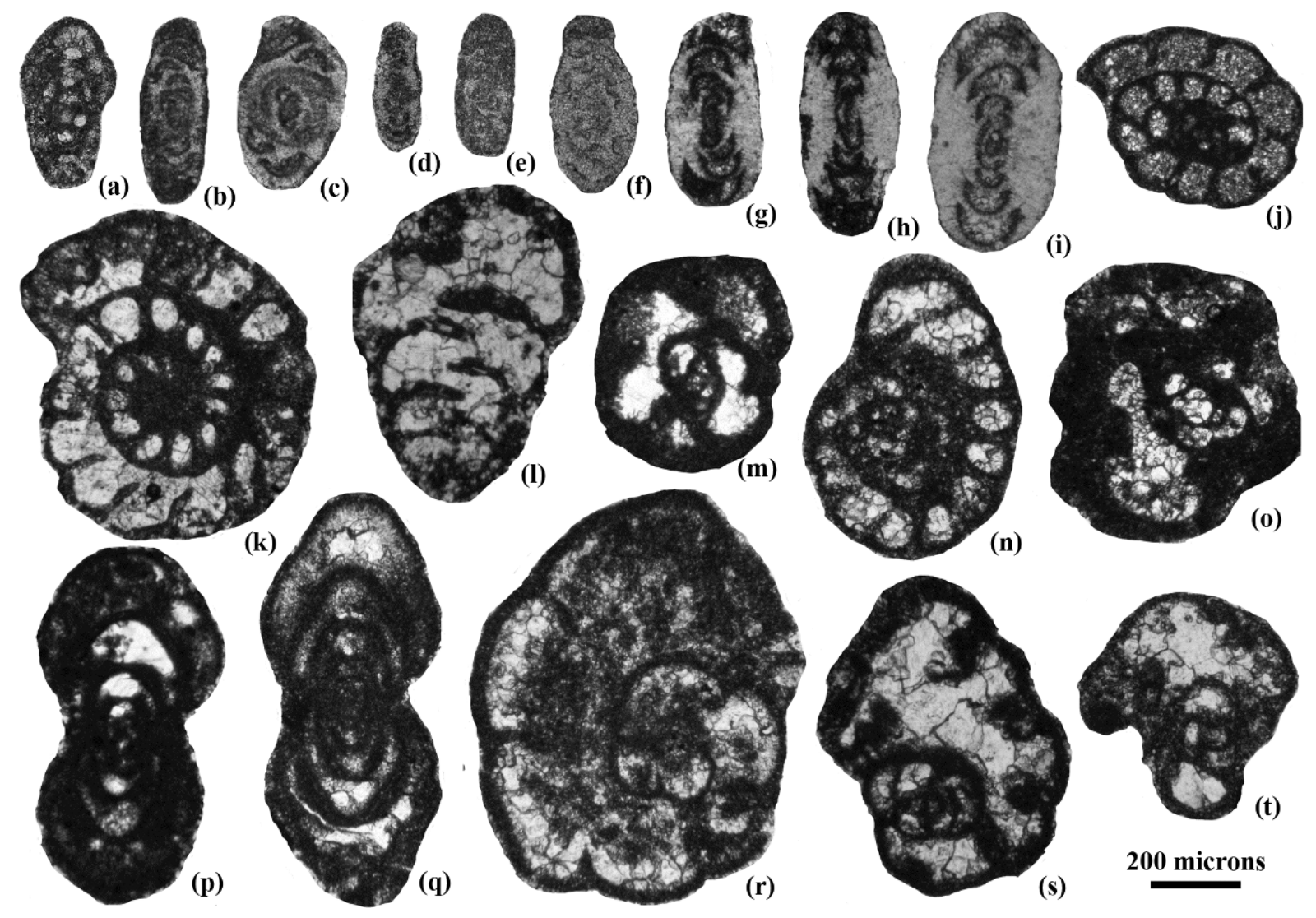

Figure 3. Selected foraminifers from the southern Askrigg Block. (a) Eoparastaffella simplex, (EWJ1573), Arundian, Chapel House Limestone Formation, Silverdale Borehole. (b)

Nodosarchaediscus demaneti, (Pc4822), late Asbian, Cove Limestone Member, Conistone Dib. (c) Archaediscus at angulatus stage, (Pc4822), late Asbian, Cove Limestone Member, Conistone Dib. (d) Neoarchaediscus aff. incertus (primitive), (EWJ1554), late Asbian, Scaleber Quarry Limestone Member, Silverdale Borehole. (e) Neoarchaediscus sp. (primitive), (Pc4825), late Asbian, Cove Limestone Member, Conistone Dib. (f) Neoarchaediscus stellatus, (EWJ1516), latest Asbian-Brigantian interval, Gordale Limestone Member, Silverdale Borehole. (g) Glomodiscus rigens, (EWJ1575), Arundian, Chapel House Limestone Formation, Silverdale Borehole. (h) Uralodiscus adindanii, (EWJ1575), Arundian, Chapel House Formation, Silverdale Borehole. (i) Uralodiscus settlensis, (EWJ1575), Arundian, Chapel House Limestone Formation, Silverdale Borehole. (j) Endothyranopsis cf. compressa, (EWJ1573), Arundian, Chapel House Limestone Formation, Silverdale Borehole. (k) Endothyranopsis compressa, (EWJ1562), Holkerian, Scaleber Quarry Limestone Member, Silverdale Borehole. (1) Koskinotextularia sp., (EWJ1562), Holkerian, Scaleber Quarry Limestone Member, Silverdale Borehole. (m) Holkeria sp., (EWJ1563), Holkerian, Scaleber Quarry Limestone Member, Silverdale Borehole. (n) Pojarkovella nibelis, (WQ215), late Asbian, Gordale Limestone Member, Coldstones Quarry. (o) Condrustella sp., (EWJ1573), Arundian, Chapel House Limestone Formation, Silverdale Borehole. (p) Eostaffella parastruvei, (EWJ1562), Holkerian, Scaleber Quarry Limestone Member, Silverdale Borehole. (q) Pseudoendothyra sublimis, (DMA321), late Asbian, Cove Limestone Member, Trollers Gill. (r) Cribrospira panderi, (WQ215), late Asbian, Gordale Limestone Member, Coldstones Quarry. (s) Bibradya grandis, (WQ205), latest Asbian, Gordale Limestone Member, Coldstones Quarry. (t) Bibradya inflata, (EWJ1531), latest Asbian, Gordale Limestone Member, Silverdale Borehole. 


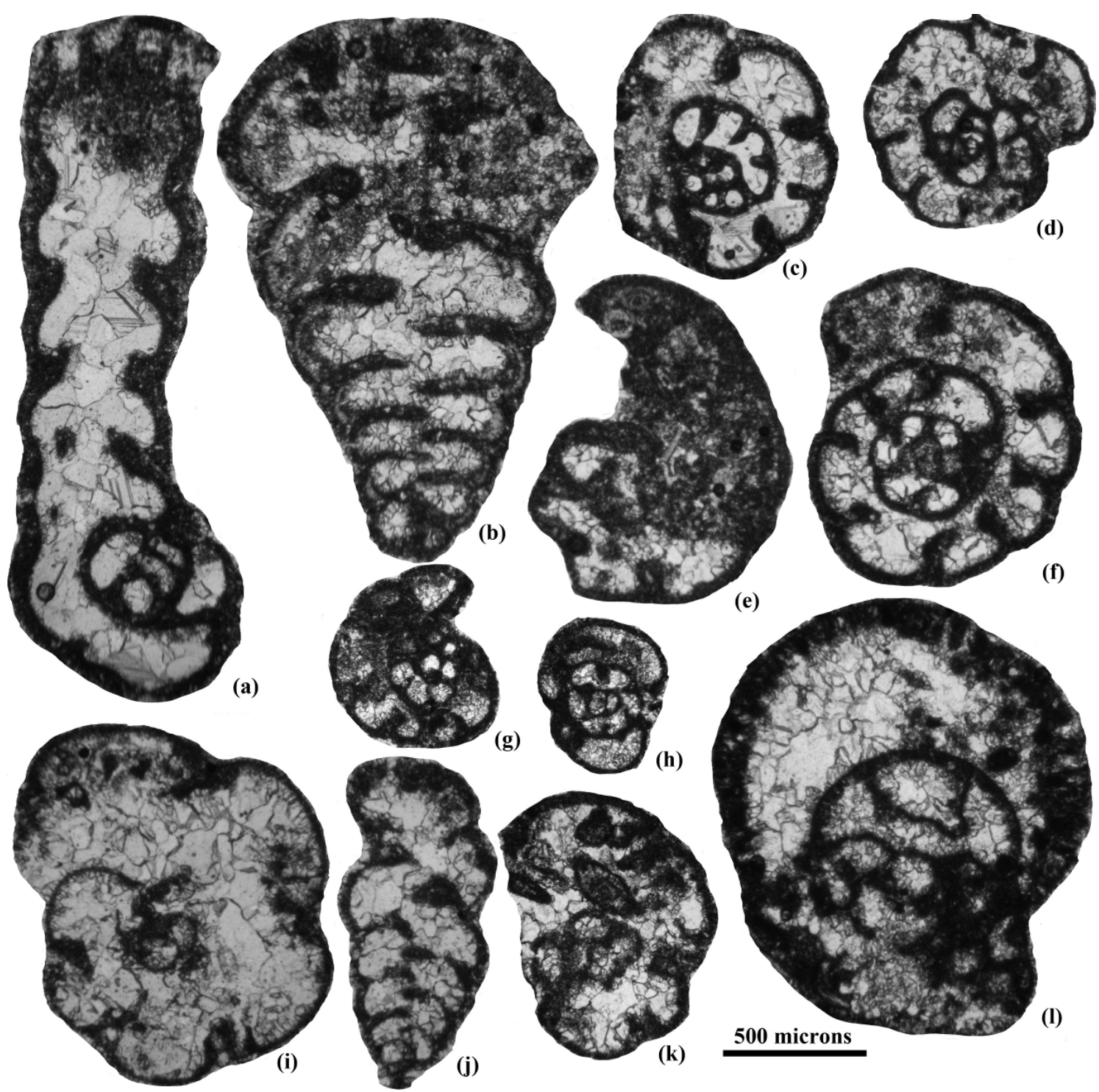

Figure 4. Selected foraminifers from the southern Askrigg Block. (a) Lituotubella magna, (EWJ1573), Arundian, Chapel House Limestone Formation, Silverdale Borehole. (b) Cribrostomum lecomptei, (EWJ1514), latest Asbian-Brigantian interval, Gordale Limestone Member, Silverdale Borehole. (c) Latiendothyranopsis menneri solida, (EWJ1573), Arundian, Chapel House Limestone Formation, Silverdale Borehole. (d) Omphalotis minima, (EWJ1556), early Asbian, Scaleber Quarry Limestone Member, Silverdale Borehole. (e) Janischewskina? sp. (primitive), (EWJ1516), latest Asbian-Brigantian interval, Gordale Limestone Member, Silverdale Borehole. (f) Endothyranopsis crassa, (EWJ1553), late Asbian, Cove Limestone Member, Silverdale Borehole. (g) Plectogyranopsis moraviae, (EWJ1573), Arundian, Chapel House Limestone Formation, Silverdale Borehole. (h) Plectogyranopsis settlensis, (EWJ1566), Holkerian, Scaleber Quarry Limestone Member, Silverdale Borehole. (i) Parajanischewskina brigantiensis, (EWJ1515), latest AsbianBrigantian interval, Gordale Limestone Member, Silverdale Borehole. (j) Koskinobigenerina sp., (EWJ1548), late Asbian, Cove Limestone Member, Silverdale Borehole. (k) Janischewskina? sp. (primitive), (EWJ1524), latest Asbian, Gordale Limestone Member, Silverdale Borehole. (1) Bradyina rotula, (EWJ1513), latest Asbian-Brigantian interval, Gordale Limestone Member, Silverdale Borehole. 


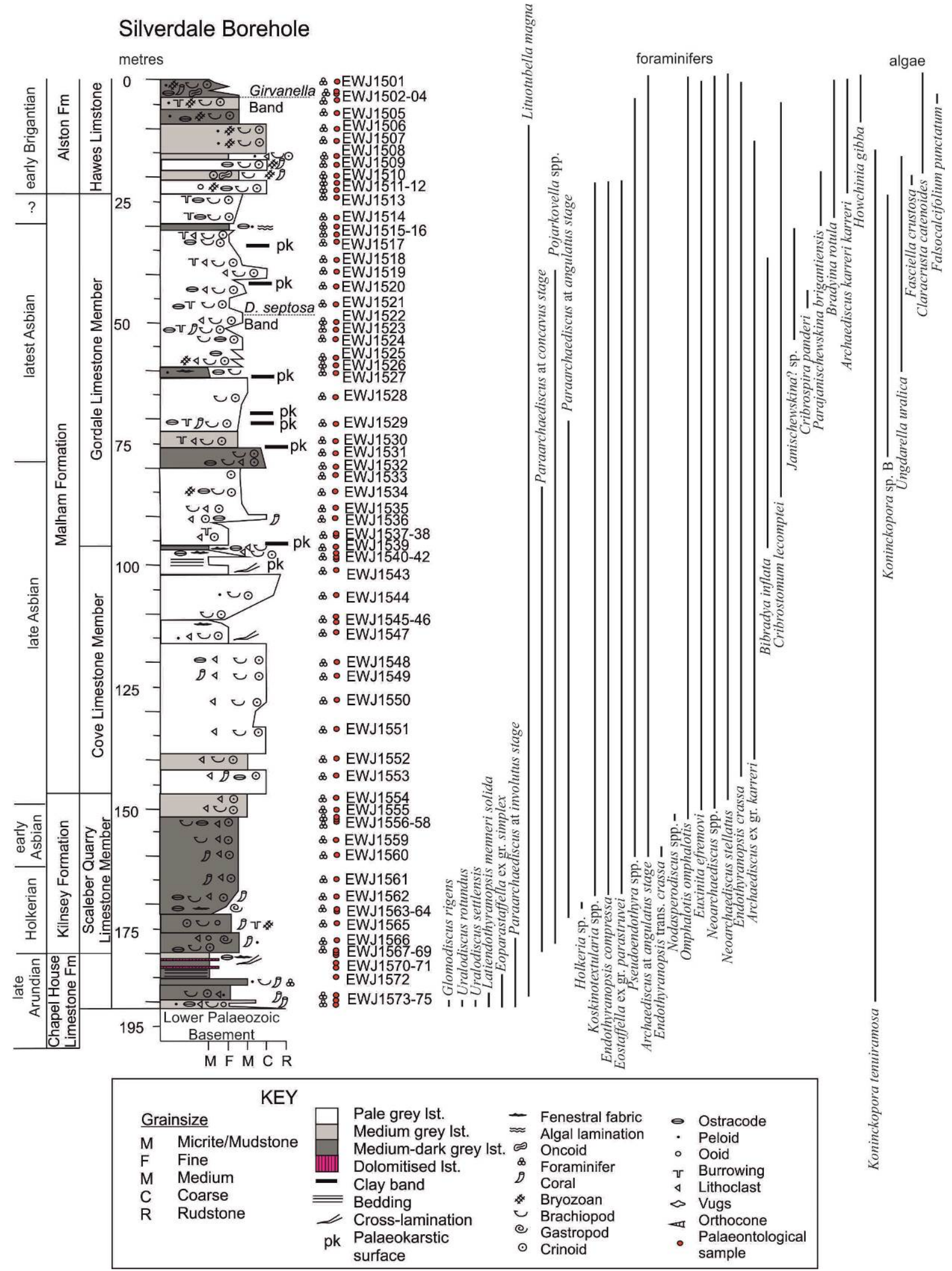

Figure 5. (Colour online) Lithological logs for the Silverdale Borehole, showing the position of biostratigraphical samples (EWJ1501-1573) and the range of key foraminifers and algae. 


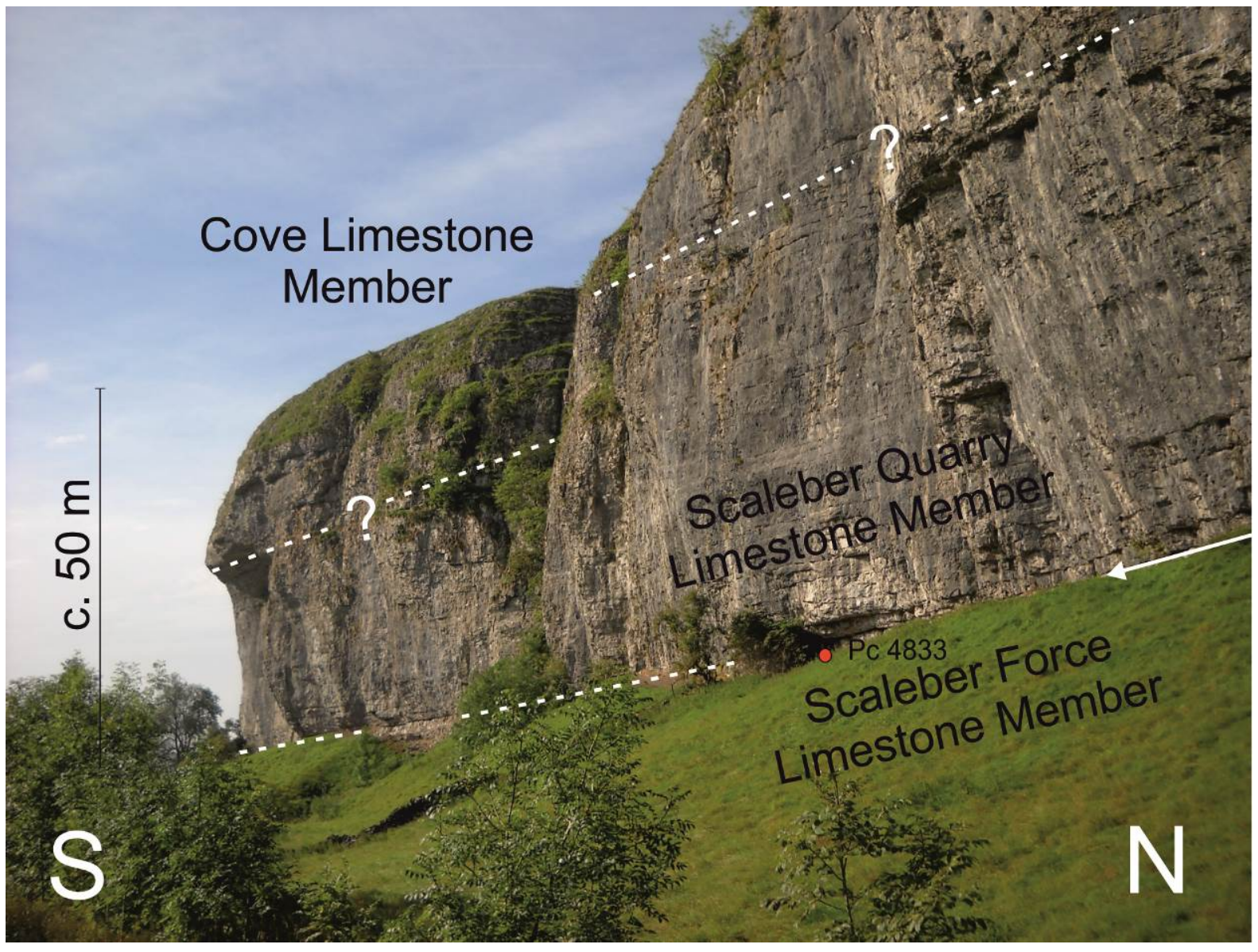

Figure 6. (Colour online) At Kilnsey Crag [3974 4681] the upper part of the Scaleber Force Limestone Member is evident beneath a prominent bedding surface near the base of the cliff (arrowed), mainly obscured by the grassy slope. The overlying Scaleber Quarry Limestone Member forms the main face and overhang. The basal part of the Cove Limestone Member (Malham Formation) caps the crag. 

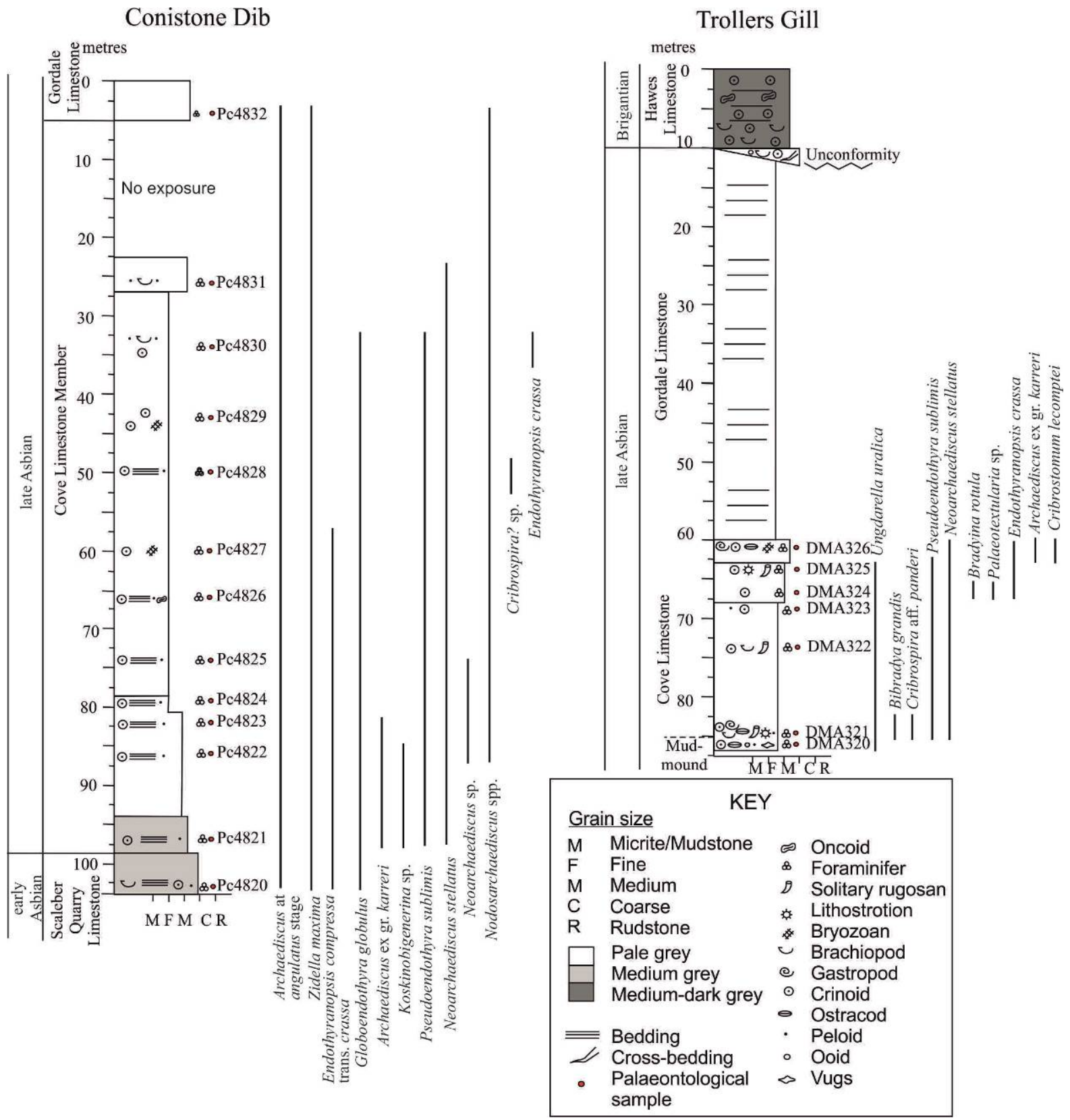

Figure 7. (Colour online) Lithological logs for key sections of the Cove Limestone at Conistone Dib and Trollers Gill, showing the position of biostratigraphical samples (Pc482032 and DMA320-26) and the range of key foraminifers and alga/algospongia. 

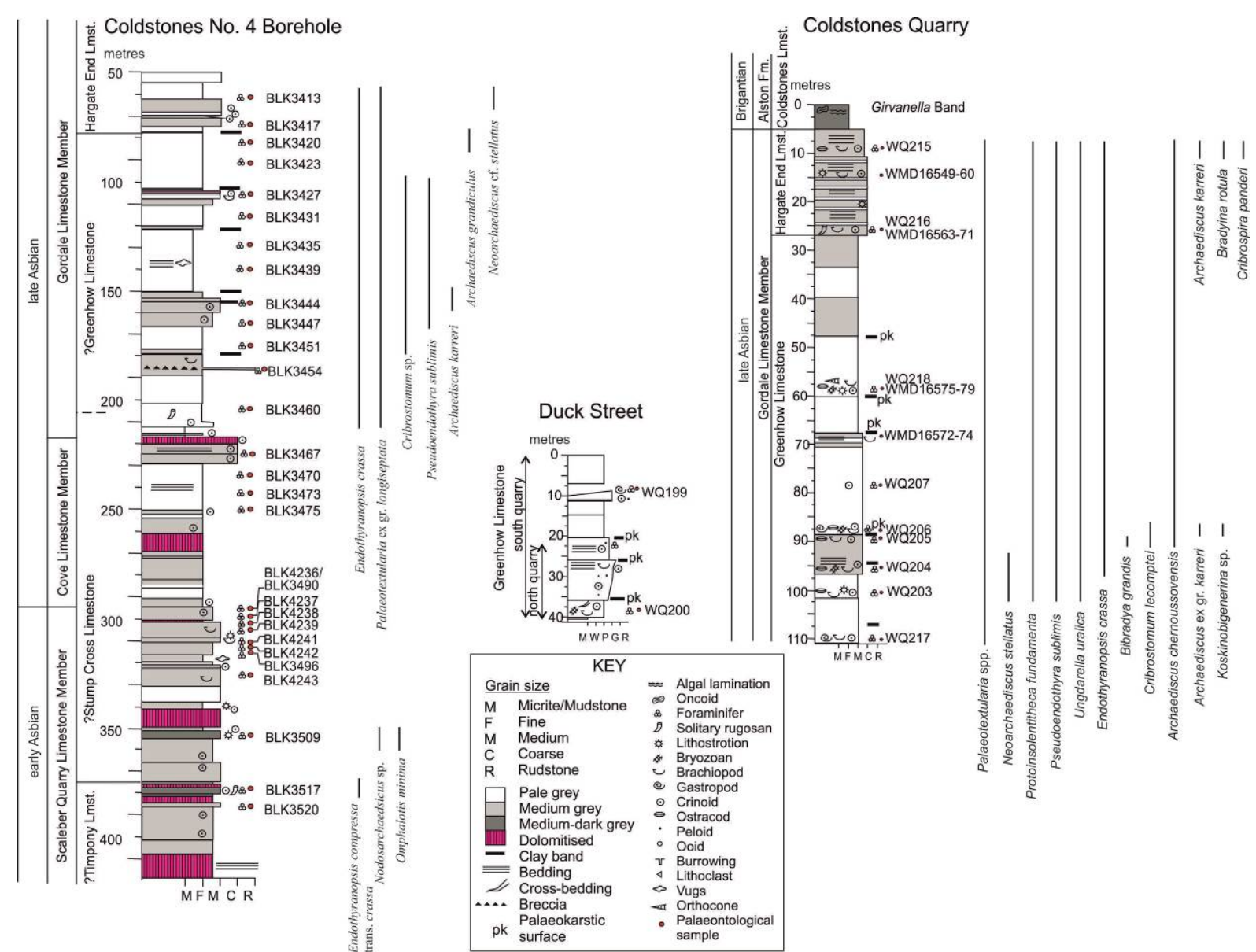

Figure 8. (Colour online) Lithological logs for key sections in the Greenhow Inlier at Duck Street, Coldstones Quarry and Coldstones No.4 Borehole, showing the position of biostratigraphical samples and the range of key foraminifers.
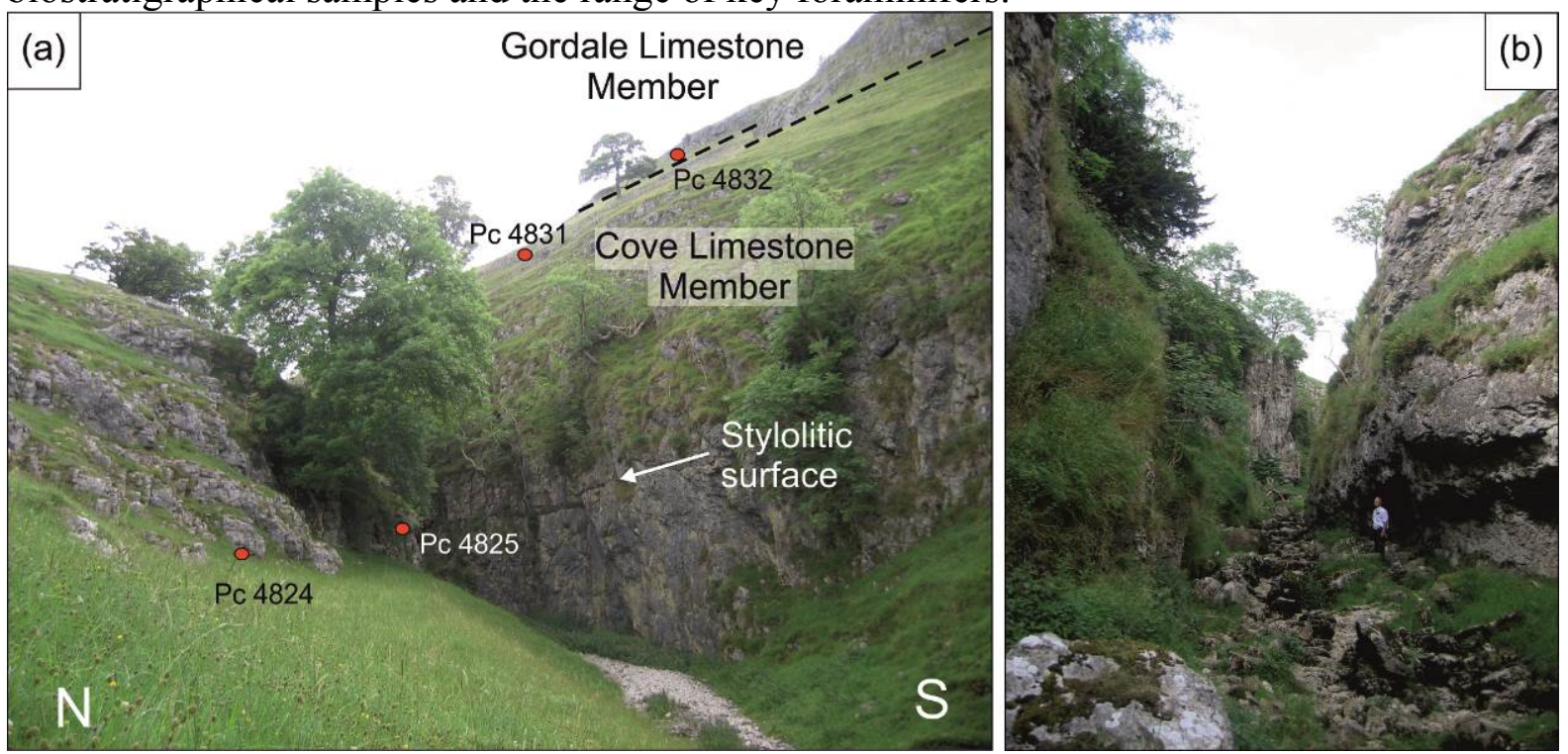

Figure 9. (Colour online) Key localities in the Cove Limestone Member. (a) at Conistone Dib [3982 4674], exposed in a meltwater drainage channel. The Gordale Limestone Member forms the distinctive crag at the top of the slope. The locations of some of the sample locations are shown. (b) Massive packstone/grainstone of the Cove Limestone Member at Trollers Gill [40687 46181]. Sample DMA320 is from the base of the right (eastern) wall of the gorge. 

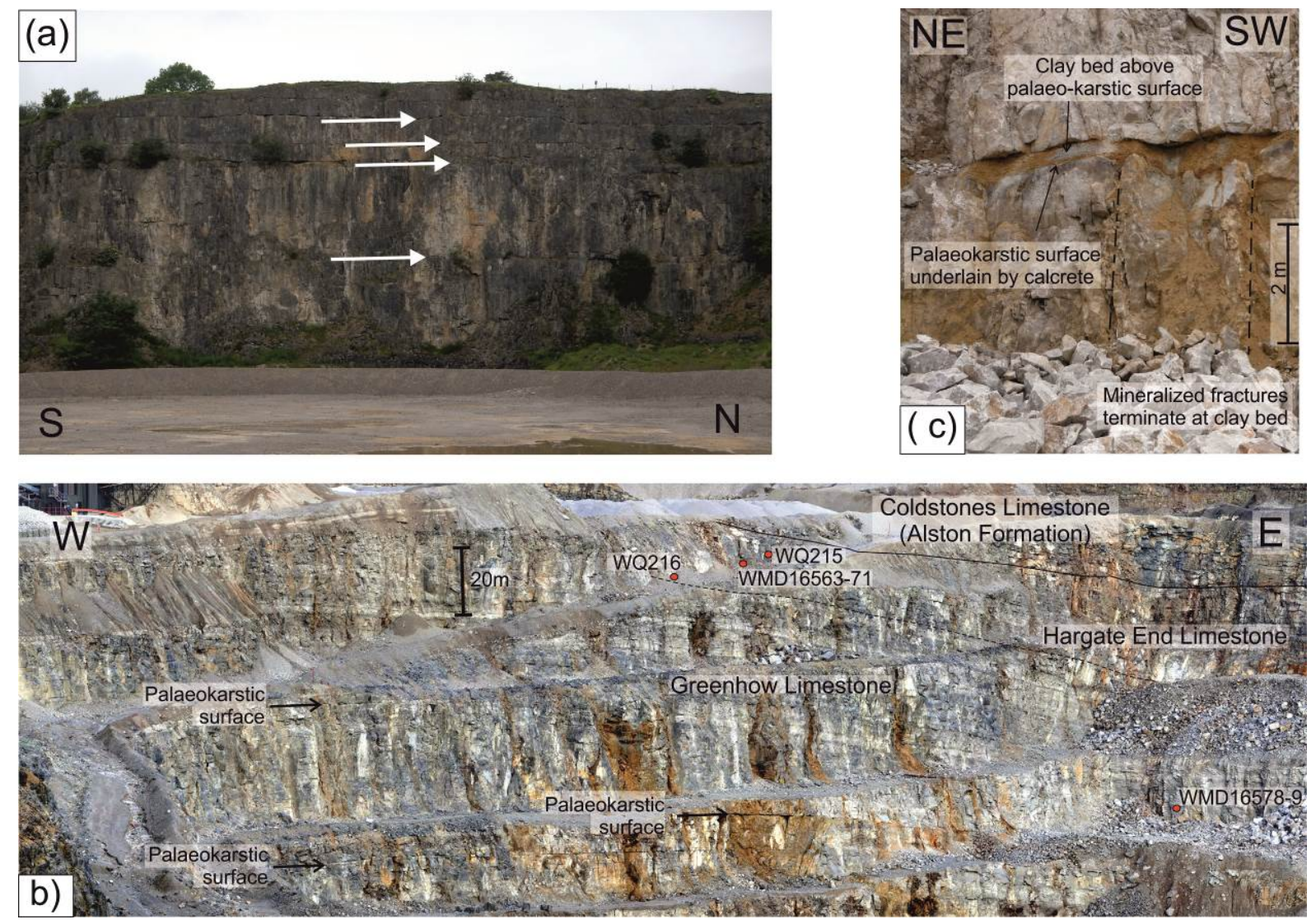

Figure 10. (Colour online) Key localities in the Gordale Limestone Member. (a) Threshfield Quarry [3975 4646] includes four prominent palaeokarstic surfaces (arrowed) with associated clay horizons. Quarry face approximately $40 \mathrm{~m}$ high. (b) Coldstones Quarry [4125 4641], showing dark grey limestone and mudstone of the Alston Formation of Brigantian age (equivalent to the Hawes, Gayle and Hardrow Scar limestones), underlain by well bedded 'Hargate End Limestone' and more weakly bedded 'Greenhow Limestone' of the Gordale Limestone Member. Photograph taken by Paul Witney. (c) Prominent palaeokarstic surface in Coldstones Quarry [41250 46396], overlain by orange clay up to $0.5 \mathrm{~m}$ thick which infills hollows present where fractures intersect the karstic surface. The packstone/grainstone is light grey and massive above the clay and light and medium grey bedded below, but with a darker grey laminar calcrete horizon present immediately beneath the palaeokarstic surface. This is the lower of two such surfaces $\sim 7 \mathrm{~m}$ apart. British Geological Survey No. P875352. 

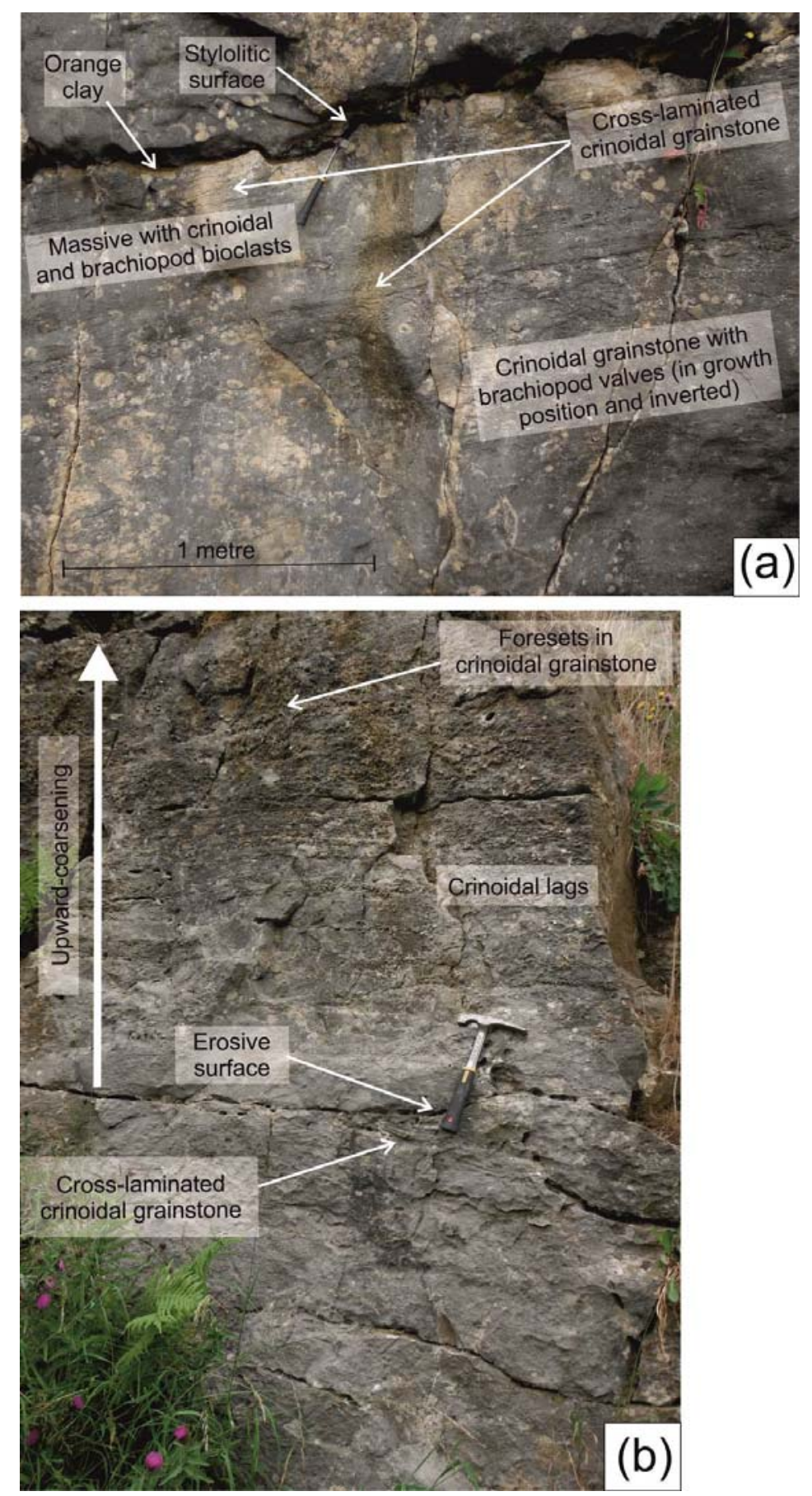

Figure 11. (Colour online) Gordale Limestone Member localities at Duck Street Quarries, Greenhow. (a) Palaeokarstic surface in south quarry [41126 46384], with some ochreous clay infill, overlain by pale grey, fine-grained, bedded grainstone with peloids, foraminifers, crinoid ossicles. The surface is underlain by a pale grey, medium-grained, peloidal grainstone, strongly laminated with crinoidal clasts, brachiopod valves and solitary corals in upper $0.6 \mathrm{~m}$, mainly massive or weakly laminated with inverted brachiopod valves, stylolitic surface with cross-lamination 3 m below top. British Geological Survey No. P875355. (b) Section in north quarry [41131 46393] showing coarse- to very coarse-grained, upward coarsening, trough and tabular cross-bedded, crinoidal packstone/grainstone/ rudstone, underlain by fine-grained bioclastic packstone/grainstone with wave ripple cross-lamination in upper $0.2 \mathrm{~m}$. British Geological Survey No. P875359. 


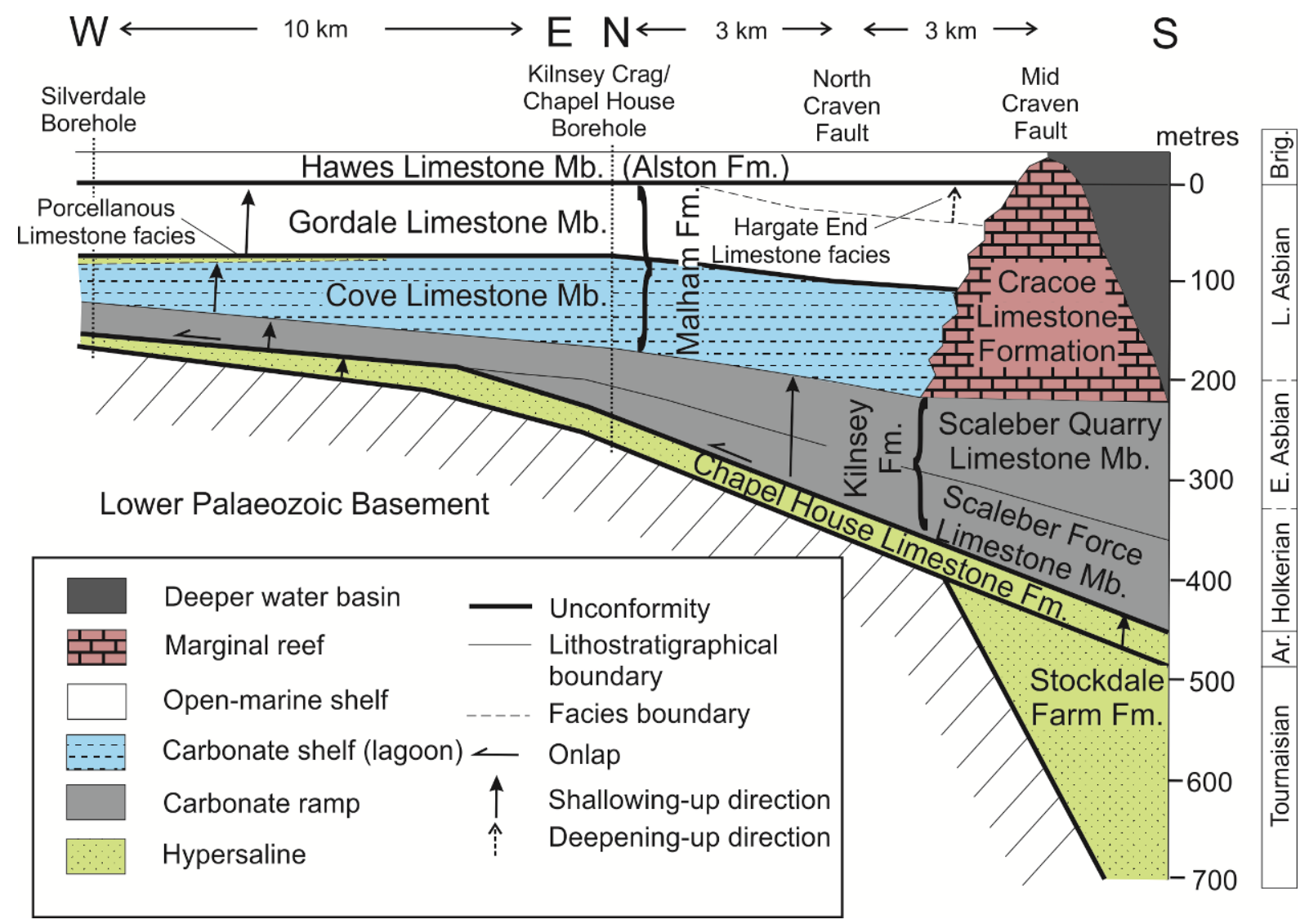

Figure 12. (Colour online) Schematic section showing the relationships between component lithostratigraphcal units of the Great Scar Limestone Group and lateral thickness variations towards the southern margin of the Askrigg Block. Approximate line of section is shown in Figure 1a. 


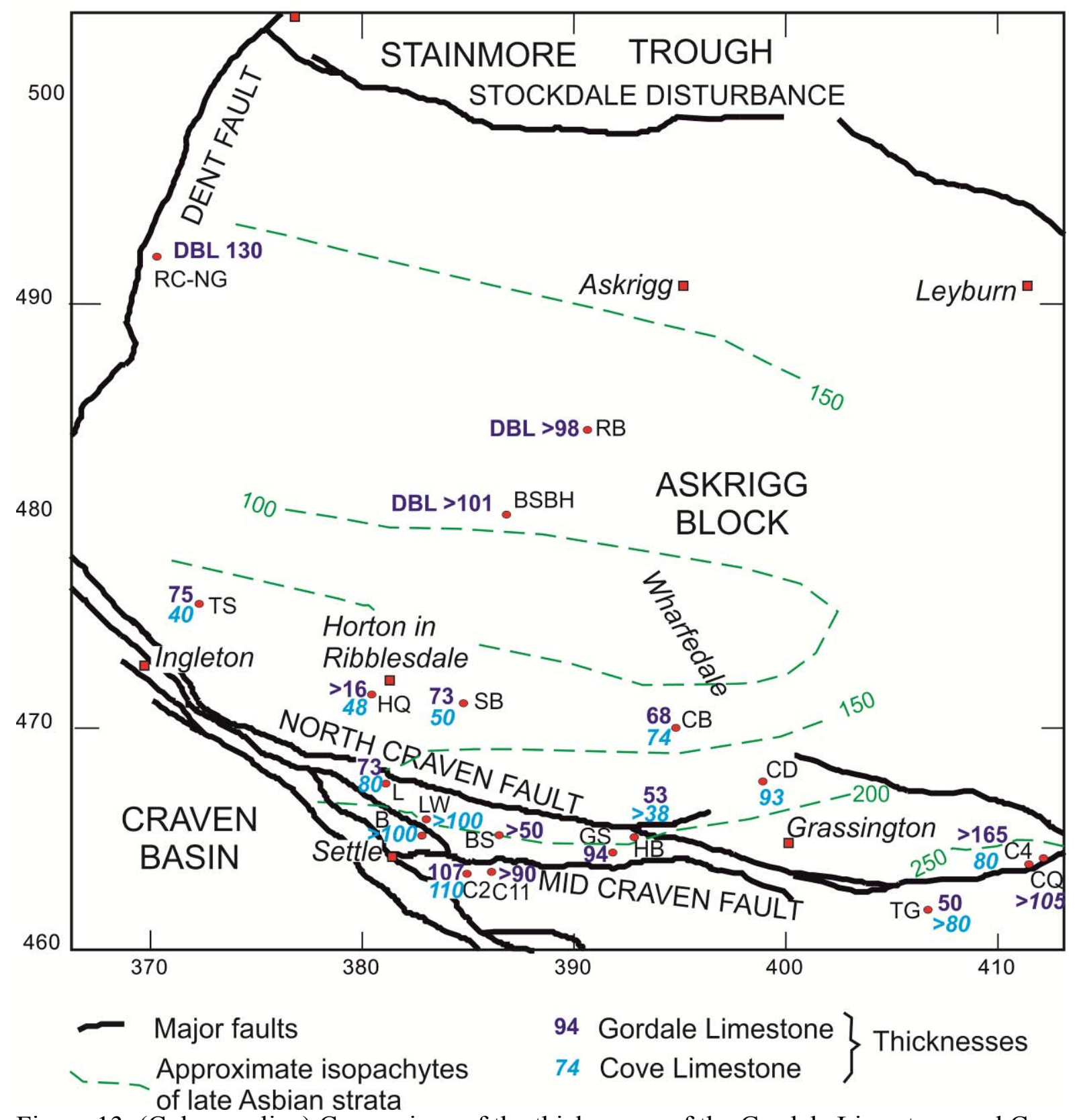

Figure 13. (Colour online) Comparison of the thicknesses of the Gordale Limestone and Cove Limestone members (Malham Formation). In the north of the Askrigg Block the figures are based upon DBL- Danny Bridge Limestone. B-Blua Crags, BS-Back Scar, BSBH -

Beckermonds Scar Borehole, C4-Coldstones No 4 Borehole, CQ-Coldstones Quarry, C2Cominco S2 Borehole, C11-Cominco S11 Borehole, CB-Cowside Beck, CD-Conistone Dib, GS-Gordale Scar, HQ-Horton Quarry, L-Langcliffe Scar, LW-Lower Winskill Borehole, RB, Raydale Borehole, RC-NG- River Clough-Nor Gill, SB-Silverdale Borehole, TG-Trollers Gill, and TS-Twistleton Scars. Thicknesses from this study and also Arthurton et al. (1988), Dunham \& Wilson (1985) and Murray (1983). Map coordinates: British National Grid.

\section{Tables}


Table 1. Historical lithostratigraphical schemes for the Great Scar Limestone Group of the Askrigg Block showing main lithological characteristics (after Dean et al., 2011 for North Askrigg and South Askrigg: Settle; after Dunham \& Wilson, 1985 for Greenhow Inlier). Modified from Waters \& Lowe (2013). 


\begin{tabular}{|c|c|c|c|c|c|c|c|c|}
\hline Formation & Member & Age & Colour & Grainsize & Lithology (main) & Lithology (subordinate) & Bedding & $\begin{array}{l}\text { Thick- } \\
\text { ness (m) }\end{array}$ \\
\hline \multicolumn{9}{|c|}{ North Askrigg Block } \\
\hline $\begin{array}{l}\text { Danny } \\
\text { Bridge } \\
\text { Limestone }\end{array}$ & & Late Asbian & $\begin{array}{l}\text { Pale to mid } \\
\text { grey }\end{array}$ & & Wackestone & $\begin{array}{l}\text { Packstone, mudstone and minor grainstone; } \\
\text { Palaeokarst surfaces overlain by bentonitic } \\
\text { clays, palaeosoils }\end{array}$ & & $102-168$ \\
\hline $\begin{array}{l}\text { Garsdale } \\
\text { Limestone }\end{array}$ & & $\begin{array}{l}\text { Late } \\
\text { Holkerian - } \\
\text { early Asbian }\end{array}$ & Dark grey & & $\begin{array}{l}\text { Wackestone with bands of } \\
\text { porcellaneous calcilutite }\end{array}$ & $\begin{array}{l}\text { Interbedded sandstone and siltstone, } \\
\text { numerous thin mudstone beds and rare thin } \\
\text { coals }\end{array}$ & & $41-58$ \\
\hline $\begin{array}{l}\text { Fawes } \\
\text { Wood } \\
\text { Limestone }\end{array}$ & & Holkerian & $\begin{array}{l}\text { Mid to dark } \\
\text { grey }\end{array}$ & & Grainstone and packstone & $\begin{array}{l}\text { Silty or stylolitic partings and some } \\
\text { porcellaneous lime-mudstone }\end{array}$ & & $55-80$ \\
\hline $\begin{array}{l}\text { Ashfell } \\
\text { Sandstone }\end{array}$ & & $\begin{array}{l}\text { Late } \\
\text { Arundian }\end{array}$ & & Fine-grained, & Sandstone & $\begin{array}{l}\text { Cross-laminated sandstone/ siltstone with } \\
\text { up to } 6 \text { limestone beds }\end{array}$ & & 38 \\
\hline $\begin{array}{l}\text { Tom Croft } \\
\text { Limestone }\end{array}$ & & Arundian & $\begin{array}{l}\text { Mid to dark } \\
\text { grey }\end{array}$ & $\begin{array}{l}\text { Medium- and } \\
\text { coarse-grained }\end{array}$ & $\begin{array}{l}\text { Grainstone, peloidal, shelly debris, } \\
\text { crinoidal, variably dolomitic }\end{array}$ & $\begin{array}{l}\text { Thin basal limestone breccia with siltstone } \\
\text { and quartz pebbles }\end{array}$ & Poorly bedded & $60-80$ \\
\hline \multicolumn{9}{|c|}{ South Askrigg Block: Settle } \\
\hline $\begin{array}{l}\text { Cracoe } \\
\text { Limestone }\end{array}$ & & $\begin{array}{l}\text { ?late } \\
\text { Holkerian - } \\
\text { Brigantian }\end{array}$ & $\begin{array}{l}\text { Mid and } \\
\text { mid-pale } \\
\text { grey }\end{array}$ & $\begin{array}{l}\text { Highly } \\
\text { variable }\end{array}$ & $\begin{array}{l}\text { Organic boundstone to packstone } \\
\text { and wackestone }\end{array}$ & $\begin{array}{l}\text { Megabrecciation and neptunian dykes } \\
\text { (crinoid- and mudstone-filled) }\end{array}$ & $\begin{array}{l}\text { Massive to } \\
\text { weakly bedded }\end{array}$ & $>100$ \\
\hline \multirow[t]{2}{*}{ Malham } & $\begin{array}{l}\text { Gordale } \\
\text { Limestone }\end{array}$ & Asbian & $\begin{array}{l}\text { Mid pale to } \\
\text { very pale } \\
\text { grey }\end{array}$ & $\begin{array}{l}\text { Fine- and } \\
\text { medium- } \\
\text { grained }\end{array}$ & $\begin{array}{l}\text { Bioclastic packstone and } \\
\text { wackestone, commonly } \\
\text { pseudobrecciated }\end{array}$ & $\begin{array}{l}\text { Cross-bedded grainstone, thin } \\
\text { conglomerates; clay beds above } \\
\text { palaeokarstic surfaces. Limestone forms } \\
\text { continuous prominent scars. }\end{array}$ & $\begin{array}{l}\text { Well bedded; } \\
\text { thick- to very } \\
\text { thick-bedded }\end{array}$ & $70-94$ \\
\hline & $\begin{array}{l}\text { Cove } \\
\text { Limestone }\end{array}$ & Holkerian & $\begin{array}{l}\text { Pale grey to } \\
\text { very pale } \\
\text { grey }\end{array}$ & $\begin{array}{l}\text { Medium- and } \\
\text { coarse-grained }\end{array}$ & $\begin{array}{l}\text { Bioclastic and peloidal packstone } \\
\text { and grainstone }\end{array}$ & $\begin{array}{l}\text { Lime-mudstone ('Porcellaneous Bed'), } \\
\text { variably fenestral; clay beds above } \\
\text { palaeokarstic surfaces }\end{array}$ & $\begin{array}{l}\text { Massive to } \\
\text { weakly bedded }\end{array}$ & $72-114$ \\
\hline \multirow[t]{2}{*}{ Kilnsey } & $\begin{array}{l}\text { Scaleber } \\
\text { Quarry } \\
\text { Limestone }\end{array}$ & Holkerian & $\begin{array}{l}\text { Mid and } \\
\text { mid dark } \\
\text { grey }\end{array}$ & $\begin{array}{l}\text { Fine- to } \\
\text { coarse-grained }\end{array}$ & Bioclastic packstone and grainstone & $\begin{array}{l}\text { Mudstone interbeds; bands and nodules of } \\
\text { black chert }\end{array}$ & $\begin{array}{l}\text { Well-bedded, } \\
\text { thin and thick }\end{array}$ & $29-134$ \\
\hline & $\begin{array}{l}\text { Scaleber } \\
\text { Force } \\
\text { Limestone }\end{array}$ & $\begin{array}{l}\text { Late } \\
\text { Arundian }\end{array}$ & Dark grey & $\begin{array}{l}\text { Fine- to } \\
\text { coarse-grained }\end{array}$ & Packstone & Wackestones, mudstone interbeds & $\begin{array}{l}\text { Well-bedded, } \\
\text { thin to thick }\end{array}$ & $22-61$ \\
\hline $\begin{array}{l}\text { Chapel } \\
\text { House } \\
\text { Limestone }\end{array}$ & & Arundian & $\begin{array}{l}\text { Mid to mid- } \\
\text { pale grey }\end{array}$ & $\begin{array}{l}\text { Medium- and } \\
\text { coarse-grained }\end{array}$ & $\begin{array}{l}\text { Calcarenite, oolitic grainstone. } \\
\text { Locally extensively dolomitised }\end{array}$ & $\begin{array}{l}\text { Basal conglomerate; interbedded siltstone } \\
\text { with sandstone and mudstone laminae; } \\
\text { dolomite mudstone and fenestral or algal } \\
\text { lime-mudstones; argillaceous wackestones }\end{array}$ & Well-bedded & $33-56$ \\
\hline \multicolumn{9}{|c|}{ South Askrigg Block: Greenhow Inlier } \\
\hline $\begin{array}{l}\text { Hargate } \\
\text { End Lst }\end{array}$ & & Late Asbian & $\begin{array}{l}\text { Dark grey } \\
\text { or mid grey }\end{array}$ & $\begin{array}{l}\text { Med.-very } \\
\text { coarse-grain }\end{array}$ & Crinoidal limestone & $\begin{array}{l}\text { Chert is present, especially near top. Base } \\
\text { taken at a single Davidsonina septosa band. }\end{array}$ & Well-bedded; & 46 \\
\hline $\begin{array}{l}\text { Greenhow } \\
\text { Limestone }\end{array}$ & & $\begin{array}{l}\text { Early - late } \\
\text { Asbian }\end{array}$ & Pale grey & $\begin{array}{l}\text { Fine- to } \\
\text { medium- } \\
\text { grained }\end{array}$ & $\begin{array}{l}\text { Sparry grainstone locally peloidal } \\
\text { and crinoidal }\end{array}$ & $\begin{array}{l}\text { Up to } 15 \text { clay beds above palaeokarstic } \\
\text { surfaces. Limestone forms continuous } \\
\text { prominent scars. }\end{array}$ & $\begin{array}{l}\text { Well-bedded; } \\
\text { thick- to very } \\
\text { thick-bedded }\end{array}$ & 120 \\
\hline $\begin{array}{l}\text { Stump } \\
\text { Cross Lst. }\end{array}$ & & $\begin{array}{l}\text { Early } \\
\text { Asbian }\end{array}$ & $\begin{array}{l}\text { Pale brown- } \\
\text { grey/grey }\end{array}$ & $\begin{array}{l}\text { Fine-med.- } \\
\text { grained }\end{array}$ & Limestone & Variably dolomitic in lower part & Poorly bedded & 84 \\
\hline $\begin{array}{l}\text { Timpony } \\
\text { Limestone }\end{array}$ & & $\begin{array}{l}\text { Holkerian-- } \\
\text { early Asbian }\end{array}$ & $\begin{array}{l}\text { Mid to dark } \\
\text { grey }\end{array}$ & Fine-grained & Limestone & $\begin{array}{l}\text { Chert nodules in upper part; shale partings } \\
\text { in lower part }\end{array}$ & $\begin{array}{l}\text { Well-bedded; } \\
\text { very thin to } \\
\text { thick bedded }\end{array}$ & $>120$ \\
\hline
\end{tabular}


Table 2. Foraminifer and algae/problematica taxa in the Kilnsey and Malham formations in the west of the study area.

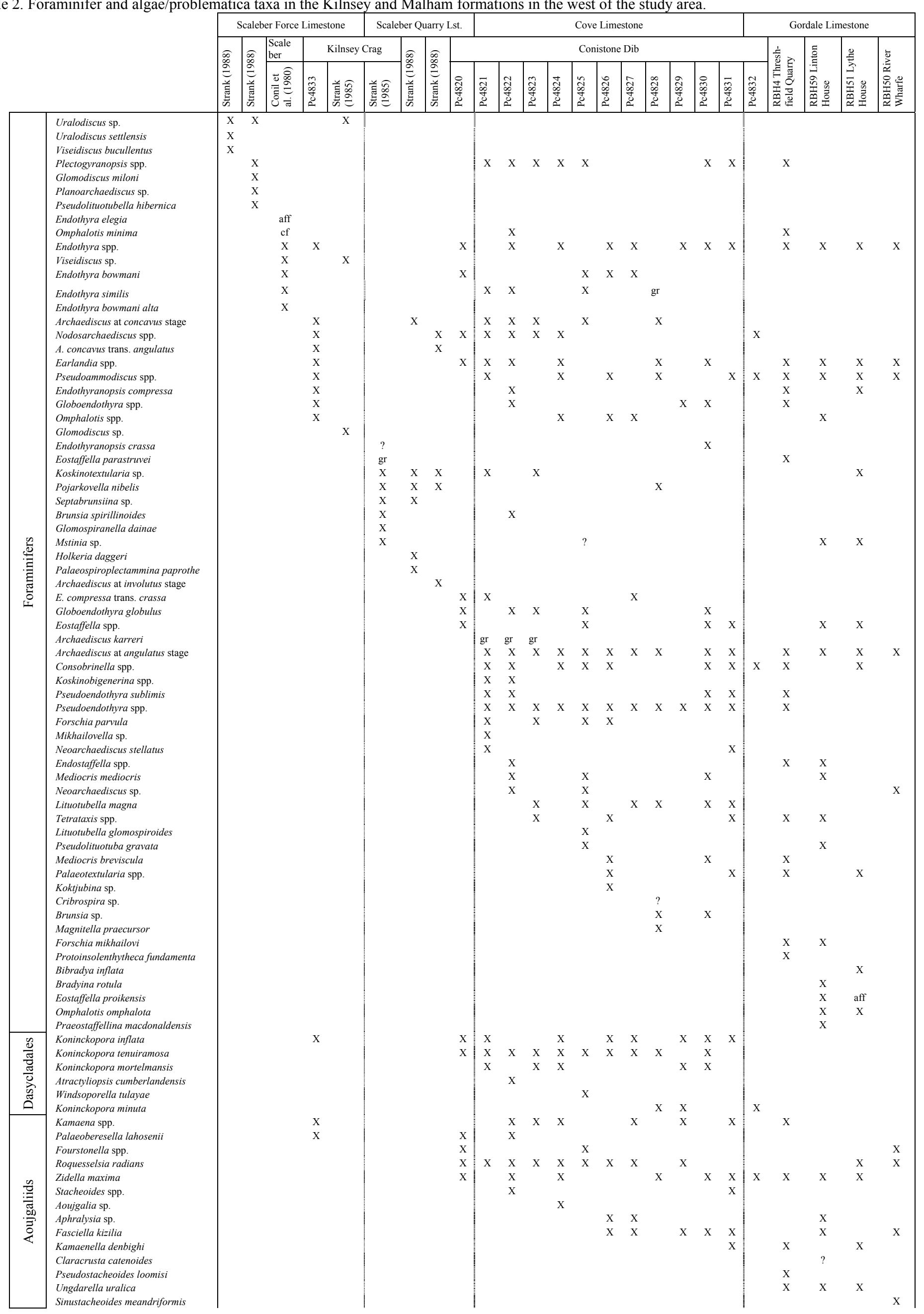


Table 3. Foraminifer and algae/problematica taxa in the Greenhow/Skyreholme inliers.

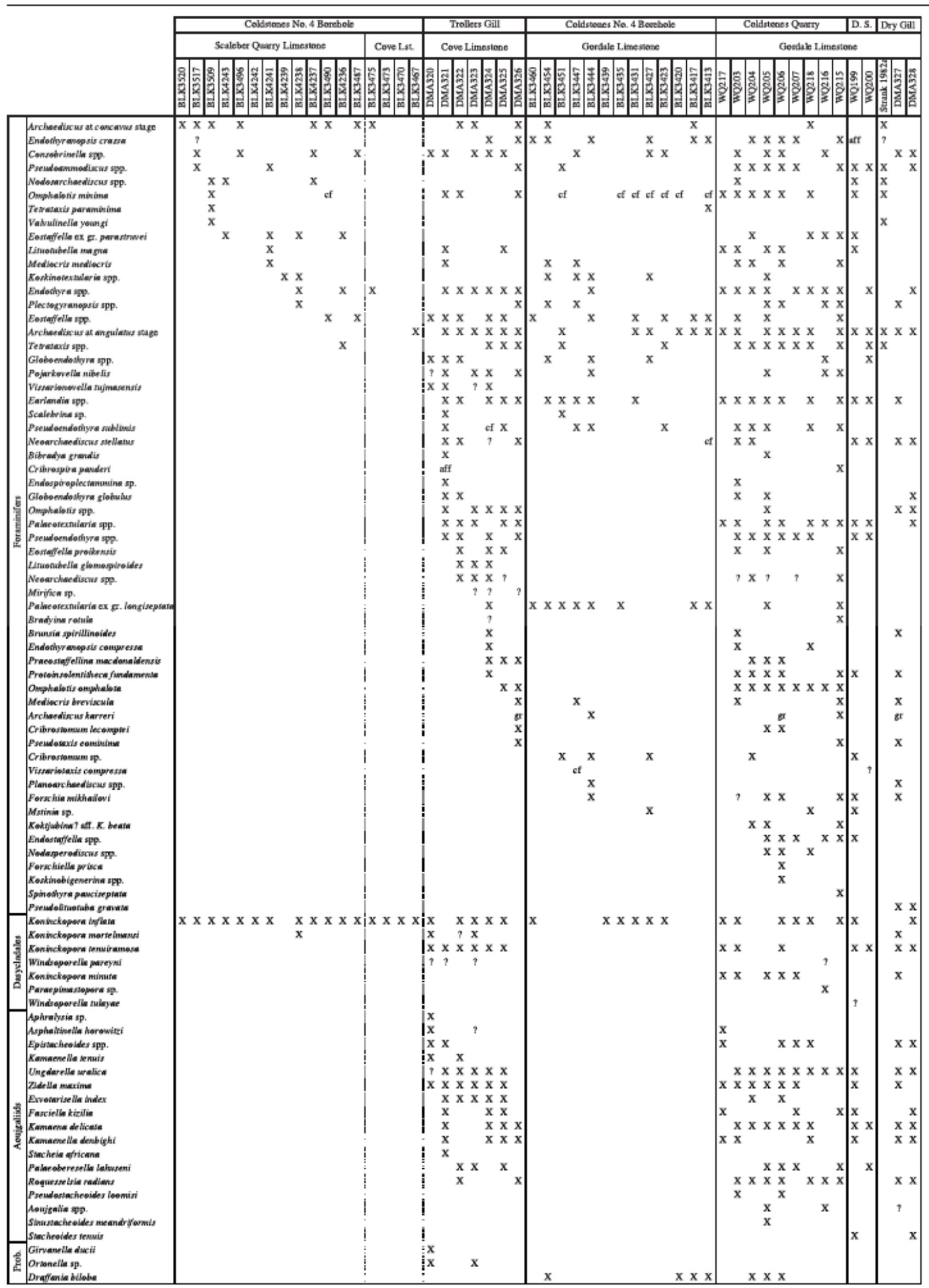


Table 4. Foraminifer and algae/problematica taxa in the Silverdale Borehole. (a) Chapel Hose Formation to Cove Limestone Member, (b) Gordale Limestone and Hawes Limestone members.

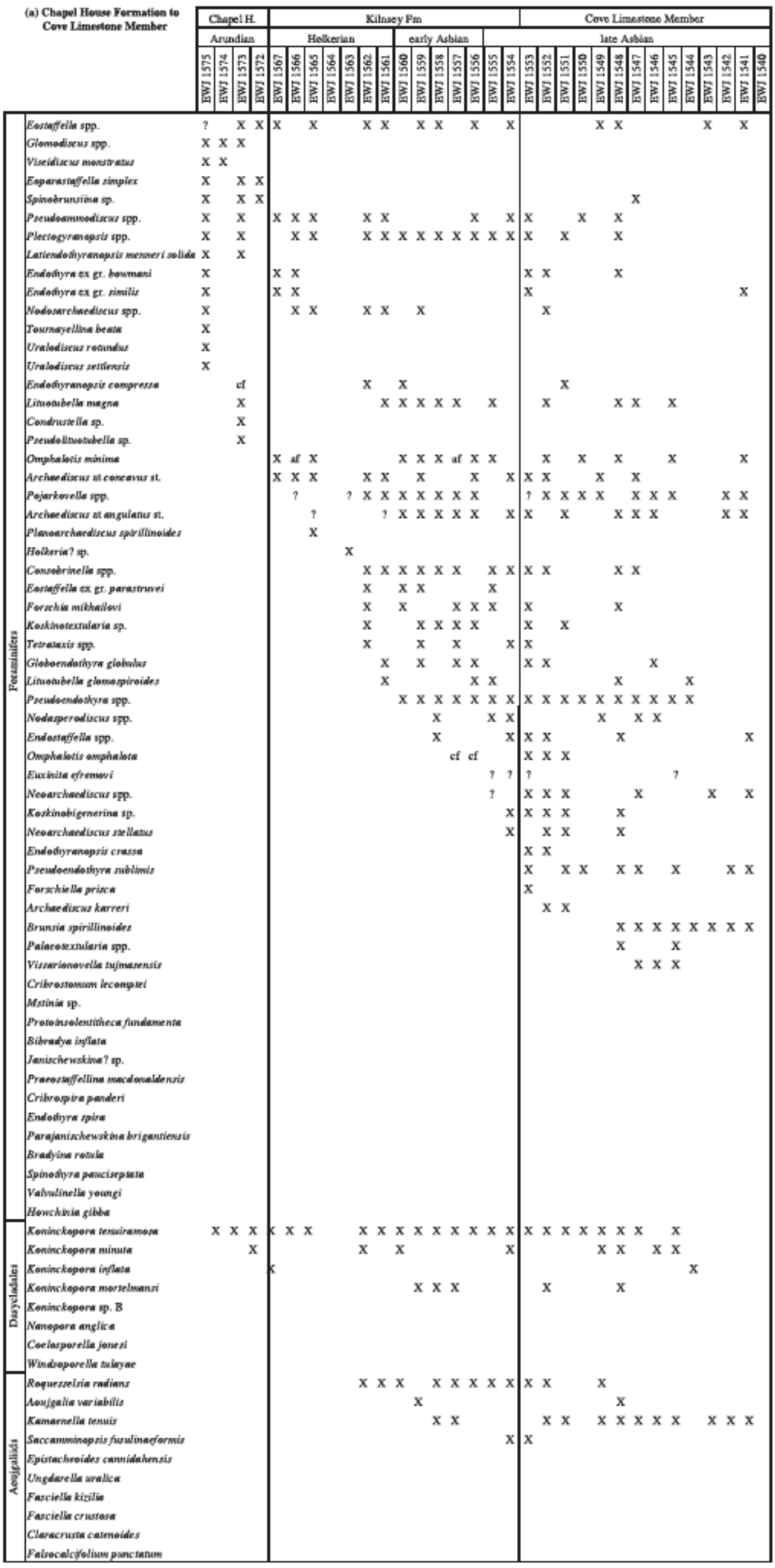




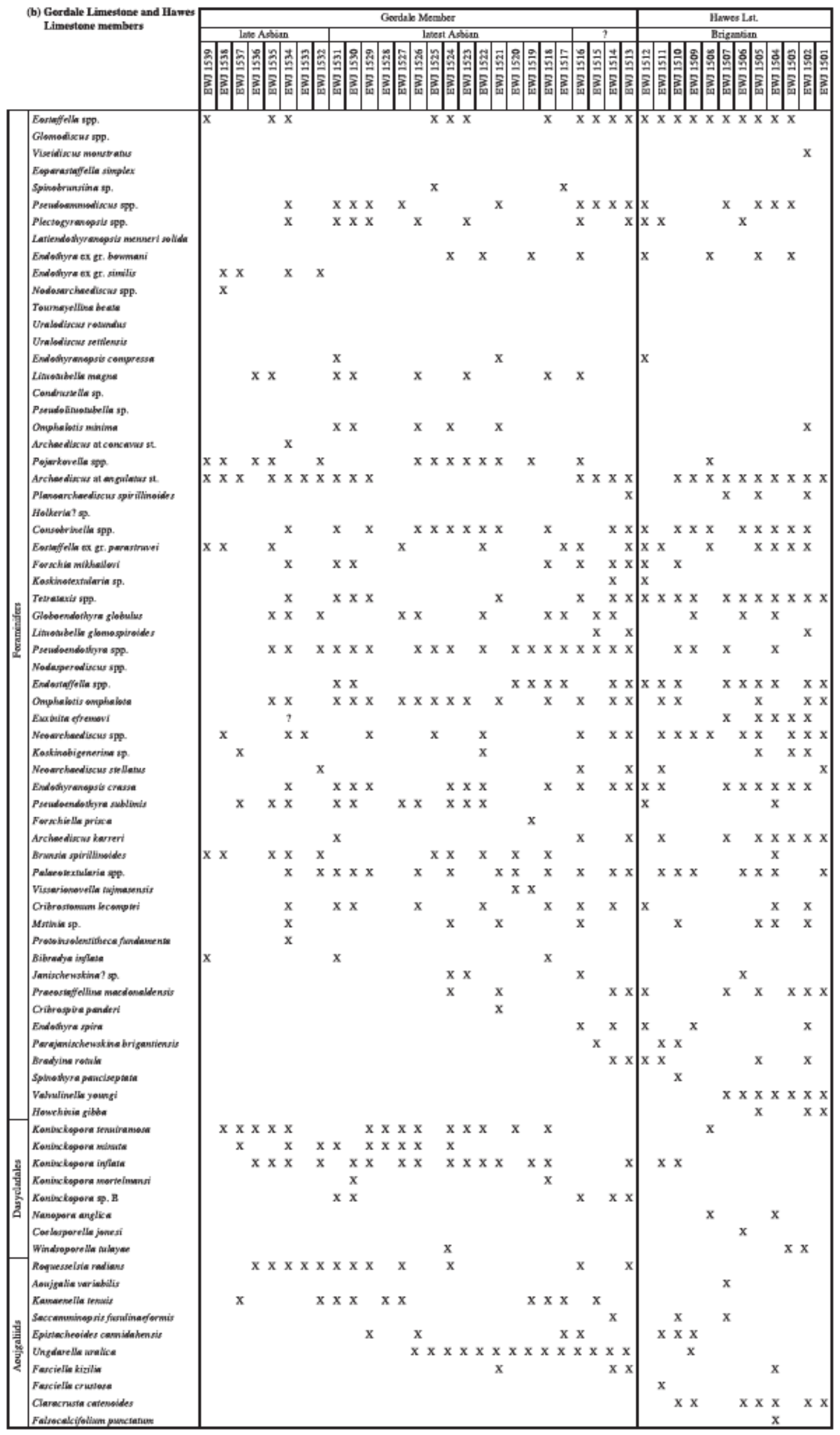


Table 5. List of specimens and locality details for the key macro- and micro-palaeontological descriptions.

\begin{tabular}{|c|c|c|c|c|}
\hline Sample Number & Easting & Northing & Location & Lithostratigraphy \\
\hline $\begin{array}{l}\text { BLK3413-17; } \\
\text { BLK3420-75 }\end{array}$ & 411780 & 464020 & Coldstones No. 4 Borehole & Gordale Limestone \\
\hline $\begin{array}{l}\text { BLK3490- } \\
\text { 3574; BLK3577 }\end{array}$ & 411780 & 464020 & Coldstones No. 4 Borehole & Cove Limestone \\
\hline DMA320 & 406870 & 461810 & Trollers Gill, Appletreewick & Cove Limestone \\
\hline DMA321 & 406860 & 461830 & Trollers Gill, Appletreewick & Cove Limestone \\
\hline DMA322 & 406850 & 461900 & Trollers Gill, Appletreewick & Cove Limestone \\
\hline DMA323 & 406850 & 461920 & Trollers Gill, Appletreewick & Cove Limestone \\
\hline DMA324 & 406850 & 461930 & Trollers Gill, Appletreewick & Cove Limestone \\
\hline DMA325 & 406860 & 461950 & Trollers Gill, Appletreewick & Cove Limestone \\
\hline DMA326 & 406870 & 461990 & Trollers Gill, Appletreewick & Cove Limestone \\
\hline DMA327-8 & 408670 & 463470 & Dry Gill, Stumps Cross, near Greenhow & Gordale Limestone \\
\hline EWJ1513-38 & 384350 & 471430 & Silverdale Borehole & Gordale Limestone \\
\hline EWJ1539-53 & 384350 & 471430 & Silverdale Borehole & Cove Limestone \\
\hline EWJ1554-67 & 384350 & 471430 & Silverdale Borehole & Scaleber Quarry Limestone \\
\hline EWJ1568-75 & 384350 & 471430 & Silverdale Borehole & Chapel House Limestone \\
\hline Pc4820 & 398286 & 467488 & Conistone Dib & Scaleber Quarry Limestone \\
\hline Pc4821 & 398315 & 467496 & Conistone Dib & Cove Limestone \\
\hline Pc4822 & 398349 & 467528 & Conistone Dib & Cove Limestone \\
\hline Pc4823-4 & 398369 & 467535 & Conistone Dib & Cove Limestone \\
\hline Pc4825 & 398414 & 467548 & Conistone Dib & Cove Limestone \\
\hline Pc4826 & 398430 & 467553 & Conistone Dib & Cove Limestone \\
\hline Pc4827 & 398439 & 467578 & Conistone Dib & Cove Limestone \\
\hline Pc4828-31 & 398444 & 467569 & Conistone Dib & Cove Limestone \\
\hline Pc4832 & 398482 & 467532 & Conistone Dib & Gordale Limestone \\
\hline Pc4833 & 397427 & 468192 & Kilnsey Crag & Scaleber Force Limestone \\
\hline RBH04 & 397719 & 464528 & Threshfield Quarry, east face & Gordale Limestone \\
\hline RBH05 & 397664 & 464686 & Threshfield Quarry north face & Gordale Limestone \\
\hline RBH50 & 402727 & 462084 & SW of Ranelands Farm, River Wharfe & Gordale Limestone \\
\hline RBH51 & 401377 & 462827 & $193 m$ east of Lythe House & Gordale Limestone \\
\hline RBH59 & 400101 & 463356 & Above Linton Falls, Bow Bridge & Gordale Limestone \\
\hline WMD16466 & 397729 & 464425 & Threshfield Quarry, near Grassington & Gordale Limestone \\
\hline WMD16467-8 & 397720 & 464503 & Threshfield Quarry, near Grassington & Gordale Limestone \\
\hline WMD16469-72 & 397719 & 464528 & Threshfield Quarry, near Grassington & Gordale Limestone \\
\hline WMD16473-82 & 397663 & 464686 & Threshfield Quarry, near Grassington & Gordale Limestone \\
\hline $\begin{array}{l}\text { WMD16549- } \\
60 ; 16563-67\end{array}$ & 412490 & 464140 & Coldstones Quarry & Gordale Limestone \\
\hline WMD16572-74 & 412450 & 463940 & Coldstones Quarry & Gordale Limestone \\
\hline WMD16575-79 & 412560 & 464060 & Coldstones Quarry & Gordale Limestone \\
\hline WQ199 & 411222 & 463826 & Duck Street South Quarry & Gordale Limestone \\
\hline WQ200 & 411315 & 463931 & Duck Street North Quarry & Gordale Limestone \\
\hline WQ203 & 412370 & 463993 & Coldstones Quarry & Gordale Limestone \\
\hline WQ204 & 412393 & 463972 & Coldstones Quarry & Gordale Limestone \\
\hline WQ205-6 & 412444 & 463989 & Coldstones Quarry & Gordale Limestone \\
\hline WQ207 & 412524 & 464078 & Coldstones Quarry & Gordale Limestone \\
\hline WQ215 & 412519 & 464136 & Coldstones Quarry & Gordale Limestone \\
\hline WQ216 & 412458 & 464155 & Coldstones Quarry & Gordale Limestone \\
\hline WQ217 & 412360 & 464019 & Coldstones Quarry & Gordale Limestone \\
\hline WQ218 & 412561 & 464104 & Coldstones Quarry & Gordale Limestone \\
\hline
\end{tabular}


